\title{
Phylogeny of Miliusa (Magnoliales: Annonaceae: Malmeoideae: Miliuseae), with descriptions of two new species from Malesia
}

\author{
Tanawat CHAOWASKU ${ }^{1} \&$ Paul J.A. KEßLER ${ }^{2}$ \\ ${ }^{1}$ Naturalis Biodiversity Center (section NHN), Leiden University, \\ P.O. Box 9514, 2300 RA Leiden, the Netherlands \\ E-mail: cyathostemma@yahoo.com (corresponding author) \\ ${ }^{2}$ Hortus botanicus Leiden, P.O. Box 9516, 2300 RA Leiden, the Netherlands
}

\begin{abstract}
The molecular phylogeny of Miliusa (Annonaceae) is reconstructed, with 27 (of ca. 50) species included, using a combination of seven plastid markers ( $r b c L$ exon, $\operatorname{trn} L$ intron, $\operatorname{trn} L-F$ spacer, mat $K$ exon, $n d h F$ exon, psbA-trnH spacer, and $y c f l$ exon) constituting ca. $7 \mathrm{~kb}$. In addition, two new species of Miliusa are described from the Malesian area: M. butonensis sp. nov. from Buton Island, Indonesia and M. viridiflora sp. nov. from Papua New Guinea. The former is included in the molecular phylogenetic analysis. The reconstructed phylogeny corresponds well to the informal morphological grouping proposed earlier. A revised key to 13 Austro-Malesian species of Miliusa is provided.
\end{abstract}

Keywords. Annonaceae, Buton Island, identification key, Papua New Guinea, molecular phylogeny.

Chaowasku T. \& Keßler P.J.A. 2013. Phylogeny of Miliusa (Magnoliales: Annonaceae: Malmeoideae: Miliuseae), with descriptions of two new species from Malesia. European Journal of Taxonomy 54: 1-21. http://dx.doi. org/10.5852/ejt.2013.54

\section{Introduction}

The genus Miliusa Lesch. ex A.DC. (de Candolle 1832) (Annonaceae) comprises approximately 50 species of shrubs, or small to large trees, distributed from the Indian subcontinent, southern China and mainland Southeast Asia to Southeast Asian islands, New Guinea (including D'Entrecasteaux Islands and Louisiade Archipelago) and northern Australia (Chaowasku \& Keßler 2006). It belongs to the tribe Miliuseae of the subfamily Malmeoideae (Chatrou et al. 2012). Members of the tribe Miliuseae are almost exclusively Asian (including New Guinea, Australia, and the western Pacific islands). Only two clades within this tribe consist of non-Asian members: one clade of four Neotropical genera and another clade of Afro-Madagascan species which are part of the recently described genus sister to Miliusa: Hubera Chaowasku (Chaowasku et al. 2012).

According to Chaowasku \& Keßler (2006), Miliusa is circumscribed by having (1) equally-sized sepals and outer petals, both of which are much smaller than the inner petals; (2) a densely hairy torus; (3) miliusoid stamens (sensu Mols \& Keßler 2003a), i.e. stamens that are loosely arranged without conspicuously dilated connective tissue covering the thecae; and (4) four-part-lamellate ruminations of the endosperm. Ten species were recognized according to the revision of the genus in the Austro-Malesian area (Mols \& Keßler 2003b). One additional species, M. lanceolata Chaowasku \& Kessler (Chaowasku 
\& Keßler 2006), was later described from D’Entrecasteaux Islands and Louisiade Archipelago, southeast off Papua New Guinea. New Miliusa species from southwestern India (Narayanan et al. 2010, 2012) as well as the Indian eastern Himalaya (Chaowasku 2013) have recently been described. Further, seven new species from Thailand are being added to this medium-sized genus by Chaowasku \& Keßler (in press) who use floral/inflorescence morphology to elaborate the four informal groups within Miliusa first introduced by Chaowasku \& Keßler (2006). These four morphological groups were the starting point to systematically study this genus further. In order to obtain additional evidence supporting the four mentioned groups, their pollen was investigated in detail (Chaowasku et al. 2008). The aim of the present study is to test whether each of the four morphological groups of Miliusa is monophyletic by means of molecular phylogenetic analysis.

In the course of selecting specimens for DNA extraction, we came across two collections, one from Buton Island (Indonesia) and another from Papua New Guinea, which are different from other described species in the Austro-Malesian area. After a thorough examination and comparison with similar species, we have concluded that they both represent undescribed species of Miliusa, which are herein formally described as M. butonensis sp. nov. and M. viridiflora sp. nov. The former is included in the molecular phylogenetic analysis. The number of Miliusa species in the Austro-Malesian area is thus increased to 13 and a key to these species is provided.

\section{Materials and Methods}

\section{Molecular phylogenetic analysis}

All accessions belong to the subfamily Malmeoideae (Appendix). Twenty-seven accessions of Miliusa covering the entire morphological variation known comprise the ingroup. The outgroups consist of 14 accessions, 11 of which were included as representatives of related genera in the tribe Miliuseae. Seven plastid markers, i.e. $r b c L$ exon, $\operatorname{trn} L$ intron, $\operatorname{trn} L-F$ spacer, matK exon, $n d h F$ exon, $p s b A$-trnH spacer, and $y c f 1$ exon, were amplified (see Table 1 for the number of included, variable, and parsimony informative characters). In total, 7033 characters, including six separately coded indels were included in the analyses. Indel coding follows Simmons \& Ochoterena (2000). The reverse complement of 15 continuous nucleotides in the $p s b A-\operatorname{trn} H$ marker for roughly half of the accessions sequenced was present and altered into the reverse complement, following Pirie et al. (2006).

All methods of DNA extraction, amplification, and sequencing performed in Chaowasku et al. (2012) were used in the present study. Due to a poor quality of the extracted DNA or unavailability of leaf material, we could not produce seven markers for all accessions (see Appendix, Table 1). Sequences were edited using the program Staden version 1.7.0 (http://staden.sourceforge.net/) and subsequently manually aligned. Some sequences were obtained from previous studies (Mols et al. 2004a, 2004b; Pirie et al. 2006; Chaowasku et al. 2012). Maximum parsimony analyses were performed in TNT version 1.1 (Goloboff et al. 2008). All characters were equally weighted and unordered. Multiple most parsimonious trees were generated by a heuristic search of the combined data, with 6000 replicates of random sequence additions, saving 10 trees per replicate, and using tree bisection and reconnection (TBR) branch swapping algorithm. Clade support was measured by symmetric resampling (SR), which is not affected by a distortion (resulting in incorrectly estimated percentages) as with some bootstrap and jackknife methods (Goloboff et al. 2003). A default change probability was used. Four hundred thousand replicates were run, each with two replicates of random sequence additions, saving one tree per replicate. Groups with SR of $\geq 85 \%, 70-84 \%$, and $\leq 69 \%$ were considered strongly, moderately, and weakly supported, respectively.

Bayesian analysis was performed in MrBayes version 3.1.2 (Ronquist \& Huelsenbeck 2003). Two independent runs were simultaneously run; each run comprised four Markov-chain-Monte-Carlo 
Table 1. Important descriptive values of sequence data. NA = not applicable.

\begin{tabular}{|l|c|c|c|c|}
\hline DNA region & $\begin{array}{c}\text { No. of included } \\
\text { characters }\end{array}$ & $\begin{array}{c}\text { No. of accessions (out of } \\
\text { all 41 accessions) lacking } \\
\text { sequence data (\%) }\end{array}$ & $\begin{array}{c}\text { No. of variable } \\
\text { characters (\%) }\end{array}$ & $\begin{array}{c}\text { No. of parsimony- } \\
\text { informative } \\
\text { characters (\%) }\end{array}$ \\
\hline $\begin{array}{l}\text { trbcL exon } \\
\text { trnL-F } \text { spacer }\end{array}$ & 1380 & $31(75.6)$ & $48(3.5)$ & $16(1.2)$ \\
\hline$m a t K$ exon & 826 & 0 & $112(12.1)$ & $46(5.0)$ \\
\hline$n d h F$ exon & 2033 & $20(48.8)$ & $78(9.4)$ & $31(3.7)$ \\
\hline $\begin{array}{l}\text { psbA-trnH } \\
\text { spacer }\end{array}$ & 431 & 0 & $225(11.1)$ & $105(5.2)$ \\
\hline$y c f 1$ exon & 1429 & 0 & $90(20.9)$ & $51(11.8)$ \\
\hline Combined data & 7027 & 0 & $220(15.4)$ & $95(6.7)$ \\
\hline
\end{tabular}

(MCMC) chains and was set for $10^{7}$ generations. The data matrix was divided into seven partitions $[\operatorname{trn} L$ intron and $\operatorname{trn} L-F$ spacer were included in the same partition $(=\operatorname{trn} L F)$ ], including a set of binary indel coding. The most appropriate model of sequence evolution for each partition was selected by Akaike information criterion (AIC) scores, using FindModel (http://www.hiv.lanl.gov/content/sequence/ findmodel/findmodel.html). The default model as well as the command 'coding=variable' were applied for the binary indel partition. The default prior settings were used except for the ratepr [=variable] and brlenspr [=unconstrained:exp(100)]. The latter prior setting was used to prevent the MCMC chains from being trapped in the areas of parameter space with unrealistically high values for the tree length parameter, resulting in a false convergence or a failure to reach convergence after hundreds of millions of generations (Marshall 2010). The temperature parameter was set to 0.1. Trees and all parameter values were sampled every $1000^{\text {th }}$ generation. Convergence of the runs was checked by both the standard deviation of split frequencies and the values for effective sample sizes (ESS) using Tracer version 1.5 (Rambaut \& Drummond 2009). The 50\% majority-rule consensus tree was generated from the two runs combined, with $10 \%$ of the first trees removed as burn-in. Groups with posterior probabilities (PP) of $\geq$ $0.96,0.91-0.95$, and $\leq 0.90$ were considered strongly, moderately, and weakly supported, respectively.

\section{Taxonomy/morphology}

Measurements/observations of the new species were made from herbarium specimens of A, BRI, CANB, E, K, L, U herbaria. The indumentum terminology follows Hewson (1988). The term 'velvety' is equivalent to densely hairy/with dense hairs, whereas 'puberulous' is equivalent to sparsely hairy/ with sparse hairs. Morphological data of the 11 known species of Miliusa in the Austro-Malesian area were from Mols \& Keßler (2003b), Chaowasku \& Keßler (2006), and personal observations (= all specimens cited in Mols \& Keßler 2003b). Morphological data of other species included in the molecular phylogenetic analysis were from Chaowasku (2013), Chaowasku \& Keßler (in press), and personal observations (= voucher specimens for molecular phylogenetic analysis plus a few more specimens, see Appendix). The term 'glandular structures' in the present study means that such structures look like glands but further anatomical confirmation is required. When only a single measurement/observation was made, the word 'circa (ca.)' was added.

\section{Results}

\section{Molecular phylogenetic analysis}

The maximum parsimony analysis of combined data sets resulted in 135 most parsimonious trees with 980 steps (results not shown). The consistency and retention indices (CI, RI) were 0.86 and 0.88 , 


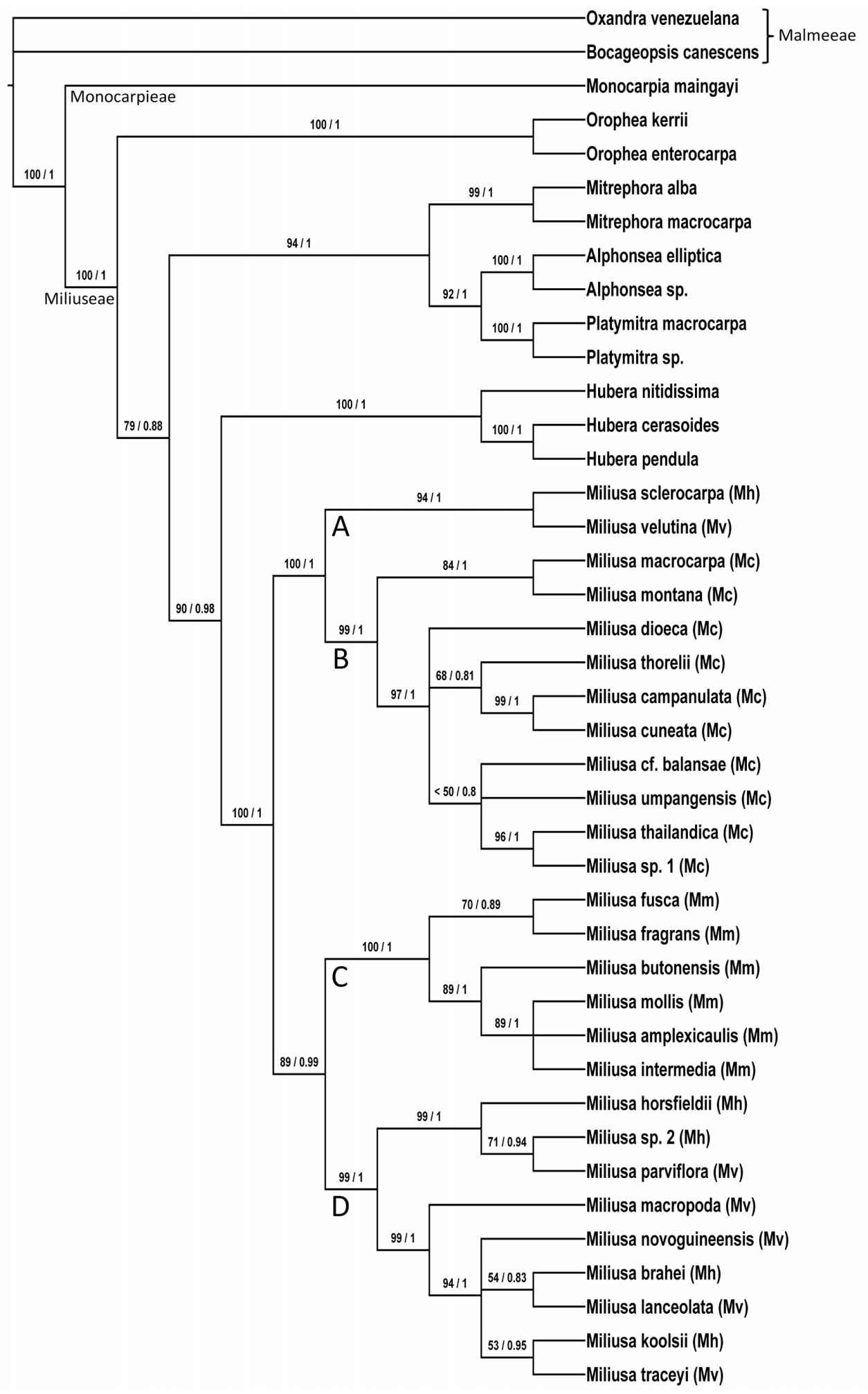

Fig. 1. 50\% Bayesian majority-rule consensus cladogram of combined seven plastid markers. Clade support: left of slash - parsimony symmetric resampling values corresponding to clades revovered in Bayesian tree; right of slash - Bayesian posterior probabilities. Mc = Miliusa campanulata Pierre group; $\mathrm{Mh}=$ Miliusa horsfieldii (Benn.) Baill. ex Pierre group; $\mathrm{Mm}=$ Miliusa mollis Pierre group; $\mathrm{Mv}=$ Miliusa velutina (DC.) Hook.f. \& Thomson group; all groups sensu Chaowasku \& Keßler (in press). 
respectively. For Bayesian analysis, the substitution model was generalized time-reversible plus gamma $(\mathrm{GTR}+\mathrm{G})$ for all partitions except the $\operatorname{trn} L F$ partition (= trnL intron $+\operatorname{trn} L-F$ spacer), which had Tamura-Nei plus gamma $(\operatorname{TrN}+\mathrm{G})$ model. The final standard deviation of split frequencies was $<0.002$ and all ESS values after discarding the burn-in were $>1200$, both indicating convergence of the runs.

Figures 1 (cladogram) and 2 (phylogram) show 50\% majority-rule consensus trees derived from the Bayesian analysis, with support values indicated in Fig. 1. Miliusa is monophyletic with maximum support (SR 100\%; PP 1.00). It is sister to Hubera with strong support (SR 90\%; PP 0.98). Within Miliusa, four strongly supported ( $\mathrm{SR} \geq 85 \%$; $\mathrm{PP} \geq 0.96$ ) clades have been identified (Fig. 1: clades A, B, C, D). Clade A is sister to clade B whereas clade C is sister to clade D, both with strong support. A clade comprising clades $\mathrm{A}$ and $\mathrm{B}$ is sister to a clade consisting of clades $\mathrm{C}$ and $\mathrm{D}$.

\section{Taxonomy}

Order Magnoliales Juss. ex Bercht. \& J.Presl (Berchtold \& Presl 1820)

Family Annonaceae Juss. (Jussieu 1789), nom. cons.

Tribe Miliuseae Hook.f. \& Thomson (Hooker \& Thomson 1855)

Genus Miliusa Lesch. ex A.DC. (de Candolle 1832)

Miliusa butonensis Chaowasku \& Kessler, sp. nov.

urn:Isid:ipni.org:names:77131155-1

Figs 3-4

\section{Diagnosis}

Miliusa butonensis sp. nov. belongs to clade C. It is best characterized by (1) dense hairs on the apical half inside the inner petals and (2) glandular structures that cover almost the whole basal half of the inner side of the inner petals.

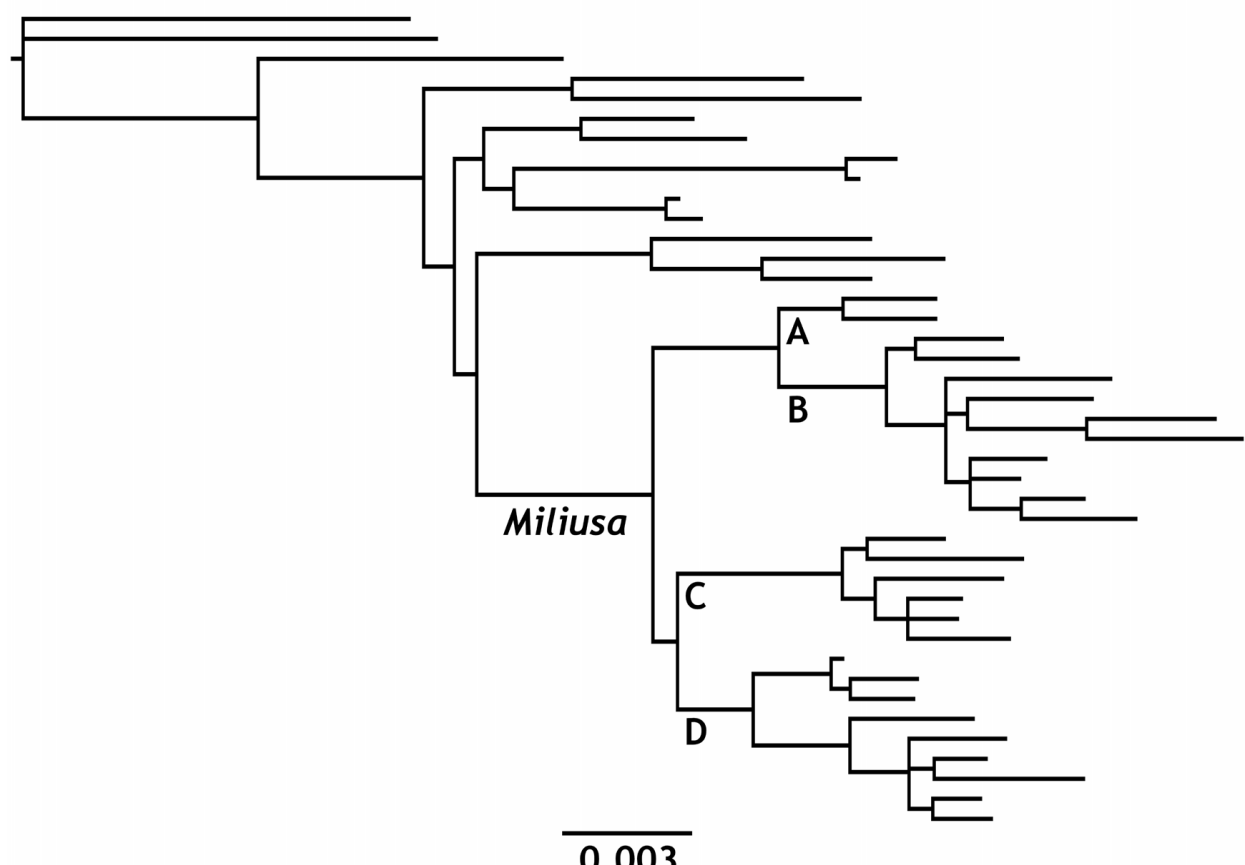

Fig. 2. 50\% Bayesian majority-rule consensus phylogram of combined seven plastid markers, showing branch length proportional to amount of lineage sequence divergence. Scale bar unit: substitution per site. 


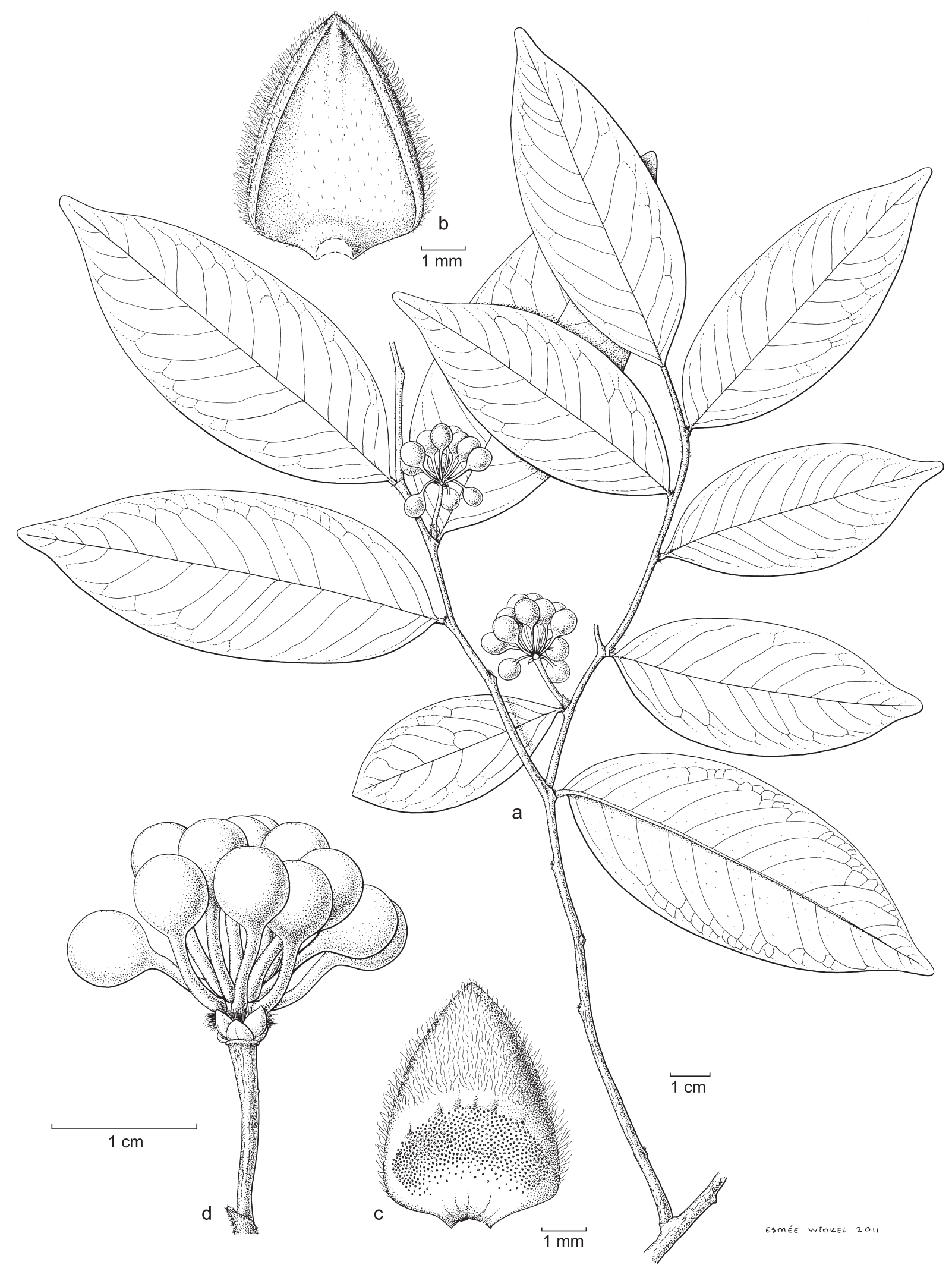

Fig. 3. Miliusa butonensis sp. nov. a. Habit. b. Outside (abaxial surface) of a persistent inner petal. c. Inside (adaxial surface) of a persistent inner petal. d. Fruit. (All from Coode 6279). Drawn by E. Winkel. 


\section{Etymology}

Named after the Buton Island (Indonesia) where this species is endemic.

\section{Type}

INDONESIA: Southeast of Sulawesi, North Buton Is., Jismil camp inland from Labuan Tobelo, Nov. 1989, Coode 6279 [holo-: U; iso-: A, K, L], in fruit (with a few persistent inner petals).

\section{Description}

Trees, ca. $8 \mathrm{~m}$ tall, ca. $10 \mathrm{~cm}$ in diameter. Young twigs appressed-puberulous. Petioles $2.0-3.0 \mathrm{~mm}$ long, appressed-puberulous. Leaves elliptic to slightly ovate, $4.7-11.1 \times 2.2-4.5 \mathrm{~cm}$, base (broadly) cuneate, sometimes slightly unequal, apex acute; lamina glabrous both sides; midrib usually slightly raised to flat above, sometimes slightly sunken, glabrous, raised below, appressed-puberulous; secondary veins $15-18$ pairs, angle with midrib $42^{\circ}-50^{\circ}$. Flowers partially known; fruiting peduncles or fruiting pedicels axillary; fruiting peduncles up to $0.4 \mathrm{~cm}$ long; fruiting pedicels $0.9-2.1 \mathrm{~cm}$ long; sepals and sometimes outer petals persistent in fruit, both ovate-triangular. Inner petals a few persistent ones fallen on herbarium sheet near the torus bearing monocarps seen, ovate-triangular, ca. $6.0 \times 4.0 \mathrm{~mm}$; outside appressed-puberulous, mostly on the middle part, margin puberulous, inside (curly-)velvety on the apical half; glandular structures observed on almost the whole basal half, slightly raised, between crescentshaped and semicircular, slightly finely warty; base not saccate. Monocarps 3-21, subglobose-ellipsoid, $0.7-0.9 \times 0.6-0.8 \mathrm{~cm}$; surface smooth, glabrous; apex not apiculate; stipe ca. $6.0 \mathrm{~mm}$ long, glabrous. Seed(s) 1 (rarely 2), subglobose(-ellipsoid), 0.6-0.8 ×0.4-0.7 cm.

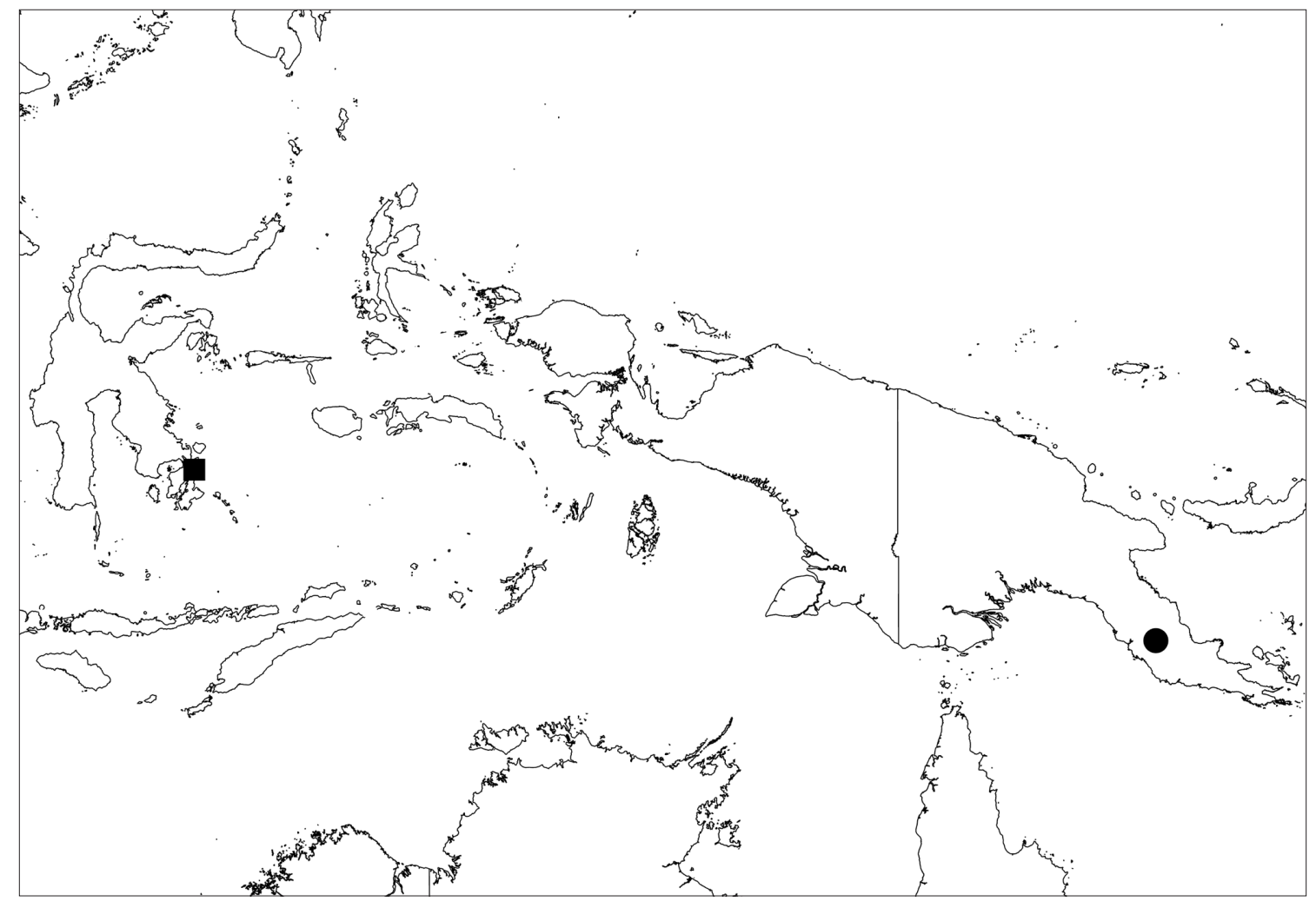

Fig. 4. Distribution of Miliusa butonensis sp. nov. (filled square) and Miliusa viridiflora sp. nov. (filled circle). 


\section{Distribution, habitat and phenology}

Indonesia (Buton Island, Fig. 4), occurring in forests on flat ridge-tops, with slightly broken canopy due to rocky terrain of raised coralline limestone. Elevation: ca. 300 m. Fruiting: November.

\section{Field notes}

Branches horizontal and foliage in flat sprays. Bark grey-brown, ca. $4 \mathrm{~mm}$ thick overall, \pm smooth with fine vertical cracks and rows of low lenticels, wood straw-colored, cut bark and wood pleasantly aromatic. Young leaves \pm yellow-green, mature leaves mid green on both sides.

\section{Miliusa viridiflora Chaowasku \& Kessler, sp. nov. urn:lsid:ipni.org:names:77131156-1}

Figs $4-5$

\section{Diagnosis}

Miliusa viridiflora sp. nov. is most morphologically similar to the recently described M. lanceolata. The new species chiefly differs in having much sparser indumentum on young twigs and lower surface of the leaf midrib, usually (broadly) elliptic leaves (narrowly ovate in M. lanceolata), and greater number of stamens (ca. 56 vs. ca. 32 in M. lanceolata) and carpels (ca. 28 vs. ca. 14 in M. lanceolata) per flower.

\section{Etymology}

The epithet refers to the light green flowers (probably also at anthesis).

\section{Type}

PAPUA NEW GUINEA: Central District, Port Moresby Subdistrict, on ridge below Boridi Village, Oct. 1973, Foreman \& Vinas LAE 60222 [holo-: L; iso-: A, BRI, CANB, E], in flower and fruit.

\section{Description}

Trees. Young twigs (almost glabrous to) appressed-puberulous. Petioles ca. $1.0 \mathrm{~mm}$ long, almost glabrous to appressed-puberulous. Leaves usually (broadly) elliptic, sometimes slightly ovate, $4.5-13.3 \times 2.1-4.9 \mathrm{~cm}$, base (broadly) cuneate to obtuse, often slightly unequal, apex acute to acuminate; lamina glabrous above, (glabrous to) appressed-puberulous below; midrib flat to slightly sunken above, almost glabrous, raised below, almost glabrous; secondary veins 11-15 pairs, angle with midrib $48^{\circ}-65^{\circ}$. Flowers usually in $\geq 7$-flowered inflorescences, terminal developing to internodal; peduncles 2.3-4.4 cm long, glabrous; rachis $2.3-4.5 \mathrm{~cm}$ long, glabrous; pedicels 5.0-13.0 cm long, glabrous, basal articulation usually observed; bracts of peduncles and inflorescence axes triangular, number depending on the number of flowers per inflorescence; pedicel bract 1 for each flower, triangular. Sepals (broadly) triangular, $0.6-0.7 \times 0.7-0.8 \mathrm{~mm}$, persistent in fruit; both sides glabrous, margin puberulous. Outer petals triangular, ca. $1.3 \times 1.0 \mathrm{~mm}$; both sides glabrous, margin puberulous. Inner petals ovate, 7.0-8.0 $\times 5.0-6.0 \mathrm{~mm}$; both sides glabrous, margin puberulous; surface of the inner side somewhat raised on the basal half compared to the apical half; base slightly saccate. Torus shortly cylindrical. Stamens ca. 56, 1.0-1.4 mm long. Carpels ca. 28 , ca. $1.3 \mathrm{~mm}$ long; stigmas capitate-globose; ovaries almost glabrous; ovules 2, lateral, uniseriate. Monocarps 2-7, subglobose-ellipsoid to slightly irregular-shaped, $0.9-1.2 \times 0.8-1.1 \mathrm{~cm}$, slightly constricted between seeds when two seeds present in the monocarps; surface slightly verruculose, glabrous; apex not apiculate; stipe 10.0-17.0 mm long, glabrous, obliquely attached to the monocarps. Seed(s) 1-2, subglobose(-ellipsoid), $0.8 \times 0.4-0.7 \mathrm{~cm}$. 


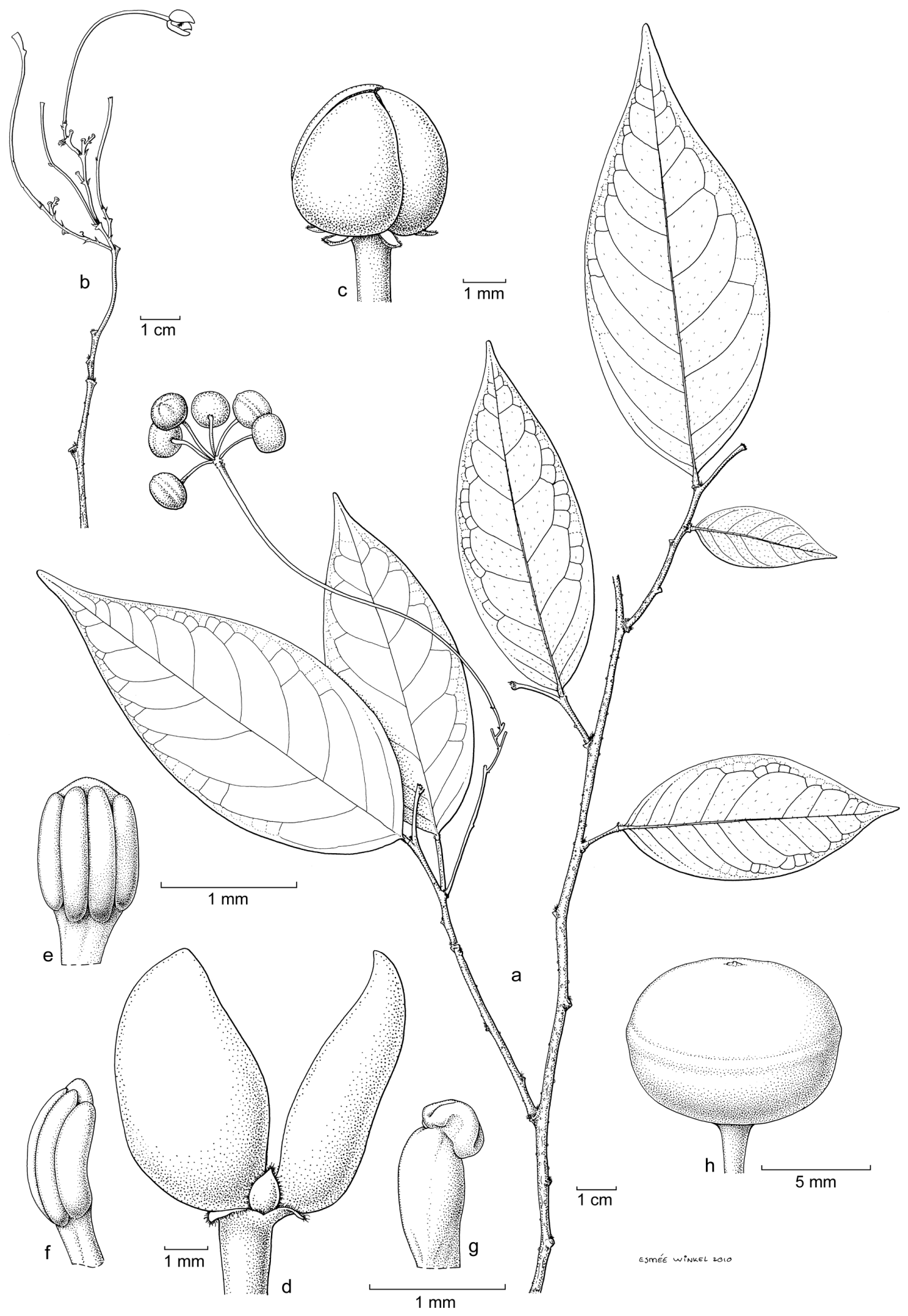

Fig. 5. Miliusa viridiflora sp. nov. a. Habit. b. Flowering twig. c. Flower bud. d. Flower with one inner petal, stamens, and carpels removed. e. Stamen, abaxial view. f. Stamen, side view. g. Carpel. h. Monocarp. (All from Foreman \& Vinas LAE 60222). Drawn by E. Winkel. 


\section{Distribution, habitat and phenology}

Papua New Guinea (Central Province, Fig. 4), occurring in secondary forests; on ridges. Elevation: ca. $1220 \mathrm{~m}$. Flowering and fruiting: October.

\section{Field notes}

A small tree. Leaves mid green. Flowers light green.

\section{Key to the Austro-Malesian species of Miliusa}

\section{Notes}

In some couplets differences are small, therefore when there is any ambiguity, it is advised to consult the descriptions of relevant species.

1. Inner petals with crescent-shaped to semicircular glandular structures inside, at base or covering almost the whole basal half..

- Inner petals without pronounced glandular structures inside or with narrow glandular structures running inside along their bilateral midline....

2. Leaves $4.7-11.1 \times 2.2-4.5 \mathrm{~cm}$, base (broadly) cuneate, sometimes only slightly unequal, not clasping the twigs. Inner petals with dense hairs inside on the apical half; glandular structures inside between crescent-shaped and semicircular, located on almost the whole basal half. BUTON ISLAND (INDONESIA).

Miliusa butonensis sp. nov.

- Leaves 9.3-26.0 × 4.0-11.0 cm, base (sub-)cordate, always (moderately to notably) unequal, \pm clasping the twigs. Inner petals glabrous inside; glandular structures inside \pm crescent-shaped, located at base. THAILAND, PENINSULAR MALAYSIA.

Miliusa amplexicaulis Ridl. (Ridley 1910)

3. Inner petals reflexed at anthesis, stamens $\geq 125$ per flower. BORNEO.

Miliusa macropoda Miq. (Miquel 1865)

- Inner petals not reflexed at anthesis but sometimes the apex/apical half recurved at anthesis, stamens $\leq 65$ per flower..

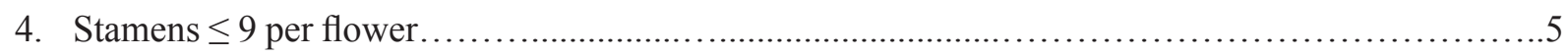

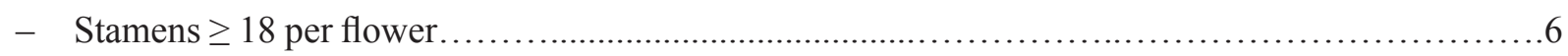

5. Sepals and outer petals $\geq 2.0 \mathrm{~mm}$ long, staminodes $4-5$ per flower, carpels $12-14$ per flower. AUSTRALIA.......................................................iliusa traceyi Jessup (Jessup 1988)

- Sepals and outer petals $\leq 1.5 \mathrm{~mm}$ long, staminode(s) up to 3 per flower, carpels 3-11 per flower. NEW GUINEA...... Miliusa novoguineensis Mols \& Kessler (Mols \& Keßler 2003b)

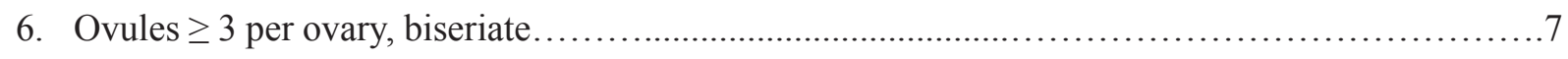

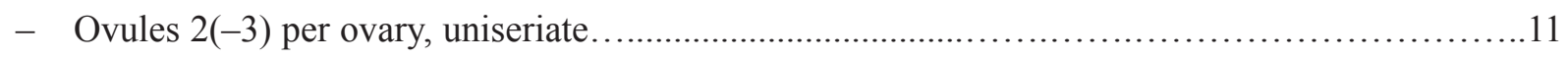

7. Inner petals without pronounced glandular structures inside. ANDAMAN AND NICOBAR ISLANDS (INDIA), THAILAND, PENINSULAR MALAYSIA, SUMATRA.

Miliusa parviflora Ridl. (Ridley 1911)

- Inner petals with narrow glandular structures running inside along their bilateral midline. 
8. Inner petals 17.0-40.0 mm long. CHINA, LAOS, THAILAND, MYANMAR, ANDAMAN AND NICOBAR ISLANDS (INDIA), PENINSULAR MALAYSIA, SOUTHEAST ASIAN ISLANDS (INCLUDING NEW GUINEA), AUSTRALIA.

Miliusa horsfieldii (Benn.) Baill. ex Pierre (Pierre 1881; basionym: Bennett 1840)

- Inner petals $\leq 15.0 \mathrm{~mm}$ long.

9. Carpels $21-27$ per flower, ovules 5-7 per ovary. AUSTRALIA.

Miliusa brahei (F.Muell.) Jessup (Jessup 1986; basionym: Mueller 1874)

- Carpels $\leq 18$ per flower, ovules $\geq 8$ per ovary.

10. Leaf base usually equal. Pedicels $0.9-2.5(-4.5) \mathrm{cm}$ long. Monocarps (1.3-)2.0-3.2 cm wide, stipe (11.0-)16.0-29.0 mm long, seeds 1.1-1.7 × 0.7-1.5 cm. NEW GUINEA.

Miliusa koolsii (Kosterm.) J.Sinclair (Sinclair 1955; basionym: Kostermans 1952)

- Leaf base unequal. Pedicels 2.9-14.5(-21.5) cm long. Monocarps 0.6-1.3 cm wide, stipe (4.0-) $10.0-16.0(-32.0) \mathrm{mm}$ long, seeds $0.6-0.8 \times 0.3-0.5 \mathrm{~cm}$. THE PHILIPPINES.....

Miliusa vidalii J.Sinclair (Sinclair 1955)

11. Flowers and/or infloresences axillary, inner petals usually tightly appressed from the base to \pm the midpoint at anthesis. THAILAND, PENINSULAR MALAYSIA, SUMATRA, JAVA.

Miliusa longipes King (King 1892)

- Flowers and/or inflorescences terminal developing to internodal, inner petals completely open at anthesis.

12. Young twigs with dense hairs (visible by naked eye). Leaves narrowly ovate, lower surface of midrib with dense hairs. Stamens ca. 32 per flower, carpels ca. 14 per flower. D'ENTRECASTEAUX ISLANDS AND LOUISIADE ARCHIPELAGO (PAPUA NEW GUINEA).

Miliusa lanceolata Chaowasku \& Kessler (Chaowasku \& Keßler 2006)

- Young twigs (almost glabrous to) sparsely hairy (visible only under a binocular). Leaves usually (broadly) elliptic, lower surface of midrib almost glabrous. Stamens ca. 56 per flower, carpels ca. 28 per flower. PAPUA NEW GUINEA...

Miliusa viridiflora sp. nov.

\section{Discussion}

Two clades, B and C, recovered in the phylogenetic trees (Figs 1,2) correspond to Miliusa campanulata Pierre (Pierre 1881) and M. mollis Pierre (Pierre 1881) groups sensu Chaowasku \& Keßler (in press), respectively. The important features characterizing the $M$. campanulata group: inner petals that are usually tightly appressed from the base to \pm the midpoint at anthesis (Fig. 6D-F), and the M. mollis group: inner petals with crescent-shaped to semicircular glandular structures inside at the base or (a bit) higher (Figs 3c; 6G-I), are thus the synapomorphies of clades B and $\mathrm{C}$, respectively. In contrast, $M$. horsfieldii (Benn.) Baill. ex Pierre (Pierre 1881; basionym: Bennett 1840) and M. velutina (DC.) Hook.f. \& Thomson (Hooker \& Thomson 1855; basionym: Dunal 1817) groups sensu Chaowasku \& Keßler (in press) each does not form a clade; clades A and D each consists of members of both groups (see Fig. 1). The $M$. velutina group seems to have been characterized principally by a likely symplesiomorphy: an absence of conspicuous glandular structures inside the inner petals (Fig. 6B, K), whereas the main feature characterizing the $M$. horsfieldii group [inner petals with narrow glandular structures running inside along their bilateral midline (Fig. 6A, J, L)] seems to have evolved multiple times in Miliusa. Detailed ancestral character reconstructions in combination with a denser taxon sampling, however, are needed before any solid conclusion on character evolution occurred in Miliusa can be drawn.

Besides the inner petal morphology, flower and/or inflorescence position also corresponds to the phylogenetic results, i.e. all species recovered in clade $\mathrm{C}$ and most species recovered in clade $\mathrm{B}$ possess 

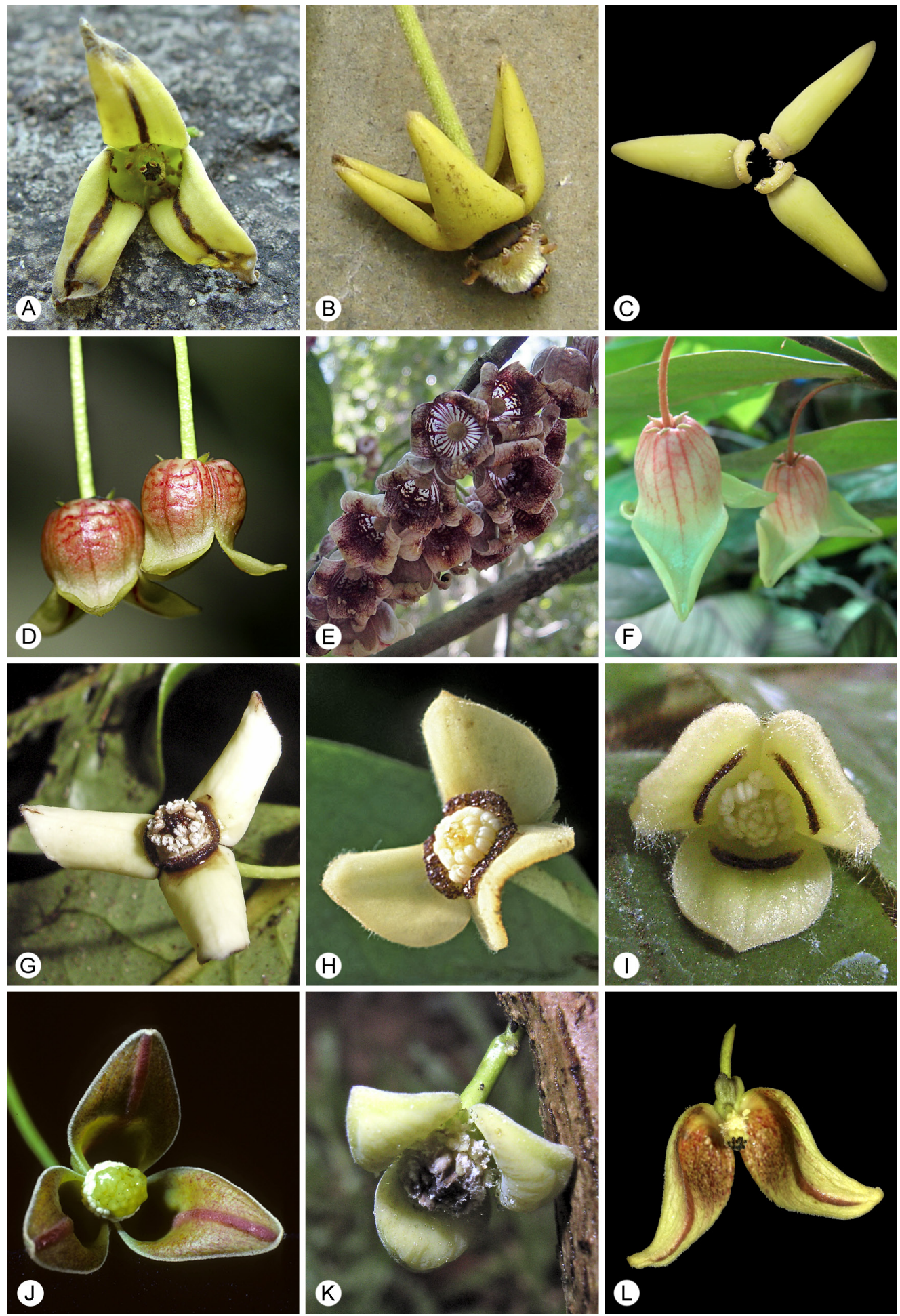

Fig. 6. Flowers/inner petals of (representatives of) Miliusa species recovered in each clade. A-C. Clade A. A. Miliusa sclerocarpa (A.DC.) Kurz. B, C. Miliusa velutina (DC.) Hook.f. \& Thomson. D-F. Clade B. D. Miliusa campanulata Pierre. E. Miliusa thorelii Finet \& Gagnep. F. Miliusa thailandica Chaowasku \& Kessler. G-I. Clade C. G. Miliusa amplexicaulis Ridl. H. Miliusa intermedia Chaowasku \& Kessler. I. Miliusa mollis Pierre. J-L. Clade D. J. Miliusa brahei (F.Muell.) Jessup. K. Miliusa parviflora Ridl. L. Miliusa sp. 2. (Photographs taken by: A: P. Keßler; B, G, I, K: T. Chaowasku; C: A. Rodphitak; D, L: B. Siriphiphat; E: S. Poungcharean; F: S. Thanapathomsinchai; H: S. Gardner; J: L. Jessup). 
axillary flowers and/or inflorescences, while all species recovered in clades A and D possess terminal (developing to internodal) flowers and/or inflorescences. This correlation shows predictive significance, e.g. species exhibiting completely open inner petals at anthesis and terminal (developing to internodal) flowers and/or inflorescences (= belonging to the M. horsfieldii or M. velutina group; see Chaowasku \& Keßler in press), but having not been included in the phylogenetic analyses are likely to belong to clade A or D.

After a thorough examination on the floral morphology of Miliusa velutina, a member of clade A (Fig. 1), peculiar structures have been observed. At the base inside the inner petals, there are thickened structures (Fig. 6C) hidden at female anthesis, but as male anthesis begins and continues, these structures are gradually becoming exposed. These structures seem to be non-glandular; however, anatomical comparisons with the glandular structures observed in the species of clade $\mathrm{C}$ (Figs 3c; 6G-I) are likely to shed light on whether they are homologous.

Miliusa butonensis sp. nov. is only known from the type specimens. Results of the molecular phylogenetic analysis, nonetheless, assure the new species status. Miliusa butonensis sp. nov. is sister to a clade comprising three mainland Asian species (Fig. 1). These three species share one remarkable feature: (sub-)cordate leaf base, whereas M. butonensis sp. nov., and the remaining species of clade C, M. fusca Pierre (Pierre 1881) and M. fragrans Chaowasku \& Kessler (Chaowasku \& Keßler in press), do not. The occurrence of this species on Buton Island is unexpected since all other species (expected to be part) of clade $\mathrm{C}$ thus far known occur on mainland Asia only. Phytochemically, it is worthwhile to note that neolignans have been found as principal secondary metabolites in two species of clade C: M. mollis (Sawasdee et al. 2010, 2013a) and M. fragrans (Sawasdee et al. 2013b), but have not been reported to occur in any species (expected to be part) of clade A, B or D so far investigated (see Sawasdee et al. 2010). If it is eventually proved that neolignans really occur only in the species (expected to be part) of clade $\mathrm{C}$, including M. butonensis sp. nov., this class of natural product could be developed as a chemotaxonomic marker.

Miliusa viridiflora sp. nov. is also only known from the type specimens; however, it is readily distinguishable from its most morphologically similar species, $M$. lanceolota, by both vegetative and generative features (see diagnosis). Additionally, the elevation where both species occur is considerably different [ca. $1220 \mathrm{~m}$ in M. viridiflora sp. nov. vs. 2-20 $\mathrm{m}$ in M. lanceolata (Chaowasku \& Keßler 2006)]. These differences convince us to recognize the former as new species.

So far neither macromorphological nor pollen morphological (see Chaowasku et al. 2008) features have been found to be able to distinguish species of clade A from those of clade D. Nevertheless, Miliusa viridiflora sp. nov. is more likely to belong to clade D because (1) clade A thus far known contains only continental Asian species and (2) all species known to occur in New Guinea belong to clade D (Fig. 1). The peduncles plus rachis (if present) plus pedicels of M. viridiflora sp. nov. (Fig. 5a, b) and of M. lanceolata (Chaowasku \& Keßler 2006) are notably long. This trait may be associated with bat dispersal syndrome since the fruits eventually set will be clearly separated from the foliage, and hence can be more easily detected (Marshall 1983). In Miliuseae, this feature has been earlier reported in some New Guinean species of Pseuduvaria Miq. (Miquel 1858) (Su \& Saunders 2006; Su et al. 2008).

It is worth conducting an anatomical investigation of the inner side of the inner petals of Miliusa to reveal the ontogeny and possible functions of the glandular [and seemingly non-glandular (e.g. Fig. 6C, E)] structures. Probably these differentiations are associated with the different pollination strategies. So far there has been no detailed study on pollination biology of Miliusa; however, according to Mols \& Keßler (2003b), fruit flies were observed to visit the flowers of M. horsfieldii. A detailed pollination biological study is required to determine if this kind of insect is potential pollinators for this species. 
Certain species of clade B exhibit \pm transparent, window-like structures at the base of the inner petals (Chaowasku \& Keßler in press), e.g. M. campanulata and M. thorelii Finet \& Gagnep. (Finet \& Gagnepain 1907; see Fig. 6E). Flies are likely to be the potential pollinators for these species as they are lured to crawl inside to the stamens/stigmas by light (Dafni 1984).

There are correlations between clades and habitat preferences in Miliusa. Most species (expected to be part) of clades A and D prefer drier habitats (e.g. deciduous/dipterocarp forests), resulting in a various degree of deciduous lifecycle exhibited by a number of species (Mols \& Keßler 2003b). In contrast, the majority of the species (expected to be part) of clades B and C prefer more humid habitats, e.g. dry/moist evergreen forests (Mols \& Keßler 2003b; Chaowasku \& Keßler in press). It is apparent that habitat shifts occurred in Miliusa; these shifts might correspond to the paleoclimate.

More species of Miliusa, especially the Indian, Philippine, and Vietnamese ones, need to be included in order to reconstruct a more robust molecular phylogeny, which will be the ground for the study in, for example, biogeography/molecular dating and character evolution.

\section{Acknowledgements}

The authors would like to thank A, AAU, BRI, CANB, CNS, E, K, L, MO, NSW, U, UC, US, WAG herbaria for the material studied, as well as two anonymous reviewers for their useful comments on the manuscript. Esmée Winkel, Ben Kieft, and Peter van Welzen (all Naturalis Biodiversity Center, section $\mathrm{NHN}$ ) are kindly acknowledged for providing the beautiful line drawings, compiling the plate, and assisting in the production of the distribution map, respectively. Aimorn Rodphitak, Bullung Siriphiphat, Laurie Jessup, Santi Poungcharean, Simon Gardner, and Suwit Thanapathomsinchai provided useful color photographs. The first author is grateful to the Royal Thai Government for granting a scholarship and providing an opportunity to study plant systematics at Leiden University.

\section{References}

Bennett J.J. 1840. Plantae Javanicae rariores. Part 2. Allen \& Co., London.

Berchtold B.V. von \& Presl J.S. 1820. O přirozenosti rostlin, aneb rostlinár, obsahugjcj: gedanj on žiwobytj rostlinném pro sebe a z ohledu giných žiwoků, podlé stawu nyněgssjbo znánj; $k$ rozssjřenj přirodnictwj; $w$ potaženj na užitećnost w rolnictwj, hospodářstwj, řemestech, uměnj i obchodu a w wztahowánj obzwlásstnjm na lekařstwj. Enders, Prague.

Candolle A.L.P.P. de 1832. Mémoire sur la famille des Anonacées, et en particulier sur les espèces du pays des Birmans. Mémoires de la Société de Physique et d'Histoire naturelle de Genève 5: 177-221.

Chaowasku T. 2013. Miliusa codonantha (Annonaceae), a new species from the Indian eastern Himalaya, with a new combination, $M$. dioeca. Willdenowia 43: 101-105. http://dx.doi.org/10.3372/wi.43.43111

Chaowasku T. \& Keßler P.J.A. 2006. Miliusa lanceolata (Annonaceae), a new species from Papua New Guinea. Blumea 51: 553-557. http://dx.doi.org/10.3767/000651906X622102

Chaowasku T., Mols J.B. \& Van der Ham R.W.J.M. 2008. Pollen morphology of Miliusa and relatives (Annonaceae). Grana 47: 175-184. http://dx.doi.org/10.1080/00173130802202305

Chaowasku T., Johnson D.M., Van der Ham R.W.J.M. \& Chatrou L.W. 2012. Characterization of Hubera (Annonaceae), a new genus segregated from Polyalthia and allied to Miliusa. Phytotaxa 69: 33-56.

Chaowasku T. \& Keßler P.J.A. In Press. Seven new species of Miliusa (Annonaceae) from Thailand. Nordic Journal of Botany. http://dx.doi.org/10.1111/j.1756-1051.2012.01785.x

Chatrou L.W., Pirie M.D., Erkens R.H.J., Couvreur T.L.P., Neubig K.M., Abbott J.R., Mols J.B., Maas J.W., Saunders R.M.K. \& Chase M.W. 2012. A new subfamilial and tribal classification of the pantropical 
flowering plant family Annonaceae informed by molecular phylogenetics. Botanical Journal of the Linnean Society 169: 5-40. http://dx.doi.org/10.1111/j.1095-8339.2012.01235.x

Dafni A. 1984. Mimicry and deception in pollination. Annual Review of Ecology and Systematics 15: 259-278. http://dx.doi.org/10.1146/annurev.es.15.110184.001355

Dunal M.F. 1817. Monographie de la famille des Anonacées. Treuttel \& Würtz, Paris.

Finet A. \& Gagnepain F. 1907. Additions à la flore de l'Asie orientale. Bulletin de la Société Botanique de France 54: 82-90.

Goloboff P.A., Farris J.S., Källersjö M., Oxelman B., Ramirez M.J. \& Szumik C.A. 2003. Improvements to resampling measures of group support. Cladistics 19: 324-332. http://dx.doi. org/10.1111/j.1096-0031.2003.tb00376.x

Goloboff P.A., Farris J.S. \& Nixon K.C. 2008. TNT, a free program for phylogenetic analysis. Cladistics 24: 774-786. http://dx.doi.org/10.1111/j.1096-0031.2008.00217.x

Hewson H.J. 1988. Plant indumentum. A handbook of terminology. Australian Flora and Fauna Series 9 , Australian Government Publishing Service, Canberra.

Hooker J.D. \& Thomson T. 1855. Flora Indica. Vol. 1. Pamplin, London.

Jessup L.W. 1986. New combinations in Australian Annonaceae. Austrobaileya 2: 227.

Jessup L.W. 1988. The genus Miliusa Leschen. ex A.DC. (Annonaceae) in Australia. Austrobaileya 2: 517-523.

Jussieu A.L. de 1789. Genera plantarum, secundum ordines naturales disposita, juxta methodum in horto regio Parisiensi exaratam, anno M.DCC.LXXIV. Herissant \& Barrois, Paris.

King G. 1892. Material for a flora of the Malay Peninsula. Journal of the Asiatic Society of Bengal, part 2, Natural History 61: 1-130.

Kostermans A.J.G.H. 1952. Notes on New Guinea plants - 4. Saccopetalum koolsii Kostermans, sp. nov. Reinwardtia 1: 459-461.

Marshall A.G. 1983. Bats, flowers and fruit: evolutionary relationships in the Old World. Biological Journal of the Linnean Society 20: 115-135. http://dx.doi.org/10.1111/j.1095-8312.1983.tb01593.x

Marshall D.C. 2010. Cryptic failure of partitioned Bayesian phylogenetic analyses: lost in the land of long trees. Systematic Biology 59: 108-117. http://dx.doi.org/10.1093/sysbio/syp080

Miquel F.A.W. 1858. Flora van Nederlandsch Indië. Vol. 1. Van der Post, Amsterdam \& Van der Post Jr., Utrecht.

Miquel F.A.W. 1865. Anonaceae Archipelagi Indici. Annales Museum Botanicum Lugduno-Batavum 2: $1-45$.

Mols J.B. \& Keßler P.J.A. 2003a. Studies in the Miliuseae. V. Review of the taxonomic history of a polyphyletic 'tribe'. Telopea 10: 113-124.

Mols J.B. \& Keßler P.J.A. 2003b. The genus Miliusa (Annonaceae) in the Austro-Malesian area. Blumea 48: 421-462. http://dx.doi.org/10.3767/000651903X489384

Mols J.B., Gravendeel B., Chatrou L.W., Pirie M.D., Bygrave P.C., Chase M.W. \& Keßler P.J.A. 2004a. Identifying clades in Asian Annonaceae: monophyletic genera in the polyphyletic Miliuseae. American Journal of Botany 91: 590-600. http://dx.doi.org/10.3732/ajb.91.4.590

Mols J.B., Co D.L.V., Gravendeel B., Chatrou L.W., Pirie M.D., Van der Ham R.W.J.M., Van Marle E.J. \& Keßler P.J.A. 2004b. Morphological character evolution in the miliusoid clade (Annonaceae). In: 
Mols J.B. (ed.) From Miliusa to Miliuseae to Miliusoid: identifying clades in Asian Annonaceae: 37-75. $\mathrm{PhD}$ thesis, Leiden University.

Mueller F.J.H. von 1874. Fragmenta phytographiae Australiae. Vol. 8. Ferres, Melbourne.

Narayanan M.K.R., Sujanapal P., Anil Kumar N., Sasidharan N. \& Sivadasan M. 2010. Miliusa wayanadica (Annonaceae), a new species from Western Ghats, India. Journal of the Botanical Research Institute of Texas 4: 63-67.

Narayanan M.K.R., Sujanapal P., Anil Kumar N., Sivadasan M., Alfarhan A.H. \& Thomas J. 2012. Miliusa gokhalaei, a new species of Annonaceae from India with notes on interrelationships, population structure and conservation status. Phytotaxa 42: 26-34.

Pierre L. 1881. Flore forestière de la Cochinchine. Doin, Paris.

Pirie M.D., Chatrou L.W., Mols J.B., Erkens R.H.J. \& Oosterhof J. 2006. 'Andean-centred' genera in the short-branch clade of Annonaceae: testing biogeographic hypotheses using phylogeny reconstruction and molecular dating. Journal of Biogeography 33: 31-46. http://dx.doi.org/10.1111/j.1365$\underline{2699.2005 .01388 . x}$

Rambaut A. \& Drummond A. 2009. Tracer. Version 1.5. Available from: http://tree.bio.ed.ac.uk/ software/tracer/ [accessed May 2011].

Ridley H.N. 1910. New or rare Malayan plants. Series 5. Journal of the Straits Branch of the Royal Asiatic Society 54: 11-13.

Ridley H.N. 1911. The flora of lower Siam. Journal of the Straits Branch of the Royal Asiatic Society 59: 63-66.

Ronquist F. \& Huelsenbeck J.P. 2003. MrBayes 3: Bayesian phylogenetic inference under mixed models. Bioinformatics 19: 1572-1574. http://dx.doi.org/10.1093/bioinformatics/btg180

Sawasdee K., Chaowasku T. \& Likhitwitayawuid K. 2010. New neolignans and a phenylpropanoid glycoside from twigs of Miliusa mollis. Molecules 15: 639-648. http://dx.doi.org/10.3390/ molecules15020639

Sawasdee K., Chaowasku T., Lipipun V., Dufat T.-H., Michel S. \& Likhitwitayawuid K. 2013a. Neolignans from leaves of Miliusa mollis. Fitoterapia 85: 49-56. http://dx.doi.org/10.1016/j.fitote.2012.12.028

Sawasdee K., Chaowasku T., Lipipun V., Dufat T.-H., Michel S. \& Likhitwitayawuid K. 2013b. New neolignans and a lignan from Miliusa fragrans, and their anti-herpetic and cytotoxic activities. Tetrahedron Letters 54: 4259-4263. http://dx.doi.org/10.1016/j.tetlet.2013.05.144

Simmons M.P. \& Ochoterena H. 2000. Gaps as characters in sequence-based phylogenetic analyses. Systematic Biology 49: 369-381. http://dx.doi.org/10.1093/sysbio/49.2.369

Sinclair J. 1955. A revision of the Malayan Annonaceae. Gardens' Bulletin, Singapore 14: 149-516.

Su Y.C.F. \& Saunders R.M.K. 2006. Monograph of Pseuduvaria (Annonaceae). Systematic Botany Monographs 79: 1-204.

Su Y.C.F., Smith G.J.D. \& Saunders R.M.K. 2008. Phylogeny of the basal angiosperm genus Pseuduvaria (Annonaceae) inferred from five chloroplast DNA regions, with interpretation of morphological character evolution. Molecular Phylogenetics and Evolution 48: 188-206. http://dx.doi.org/10.1016/j. ympev.2008.03.028 
Manuscript received: 24 March 2013

Manuscript accepted: 26 July 2013

Published on: 29 August 2013

Topic editor: Thomas Janssen

Desk editor: Natacha Beau

Printed versions of all papers are also deposited in the libraries of the institutes that are members of the EJT consortium: Muséum National d'Histoire Naturelle, Paris, France; National Botanic Garden of Belgium, Meise, Belgium; Royal Museum for Central Africa, Tervuren, Belgium; Natural History Museum, London, United Kingdom; Royal Belgian Institute of Natural Sciences, Brussels, Belgium; Natural history Museum of Denmark, Copenhagen, Denmark 


\section{Appendix}

Appendix. Voucher specimens for molecular phylogenetic analysis (with GenBank accession numbers indicated) and morphological observations.

$---=$ sequence not available for this study.

\begin{tabular}{|c|c|c|c|c|c|c|c|c|c|c|c|c|}
\hline S. & $\begin{array}{l}0 \\
0 \\
0 \\
0 \\
0 \\
0\end{array}$ & 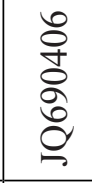 & $\begin{array}{l}\mathfrak{I} \\
\stackrel{8}{\circ} \\
8 \\
\stackrel{8}{9}\end{array}$ & 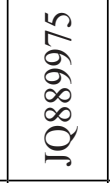 & $\begin{array}{l}0 \\
\stackrel{0}{\alpha} \\
\infty \\
0 \\
0\end{array}$ & $\begin{array}{l}\hat{\sigma} \\
\hat{\alpha} \\
\infty \\
\infty \\
\stackrel{0}{\sigma} \\
\end{array}$ & 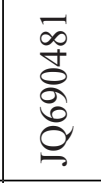 & 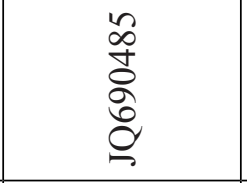 & 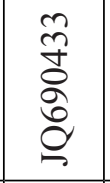 & 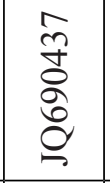 & 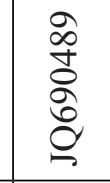 & 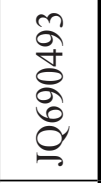 \\
\hline 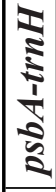 & 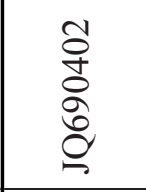 & $\begin{array}{l}n \\
0 \\
0 \\
0 \\
0 \\
0 \\
0\end{array}$ & $\begin{array}{l}\bar{F} \\
\stackrel{0}{0} \\
\stackrel{0}{0}\end{array}$ & 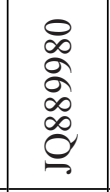 & $\begin{array}{l}\not \\
\circ \\
\infty \\
\infty \\
\stackrel{0}{0} \\
\end{array}$ & 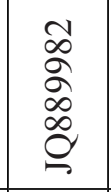 & 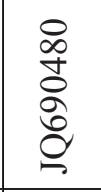 & 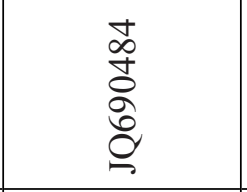 & 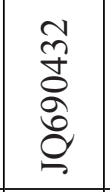 & $\begin{array}{l}0 \\
0 \\
0 \\
0 \\
8 \\
0 \\
0\end{array}$ & $\begin{array}{l}\infty \\
\infty \\
\infty \\
0 \\
\stackrel{0}{0} \\
\stackrel{d}{2}\end{array}$ & 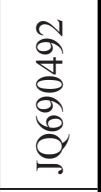 \\
\hline$\$$ & 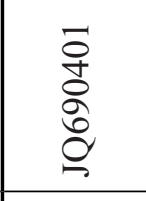 & \begin{tabular}{l}
+ \\
\multirow{2}{0}{} \\
8 \\
$\stackrel{8}{0}$ \\
0
\end{tabular} & $\begin{array}{l}\circ \\
\stackrel{+}{0} \\
\stackrel{0}{0} \\
\stackrel{0}{2}\end{array}$ & $\begin{array}{l}n \\
\infty \\
o \\
\infty \\
\infty \\
0 \\
0 \\
0\end{array}$ & 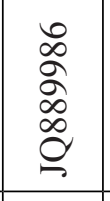 & 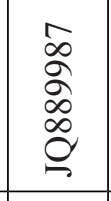 & 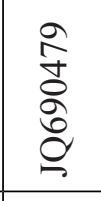 & 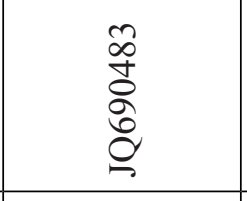 & 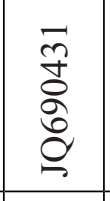 & 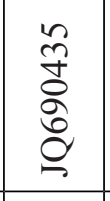 & 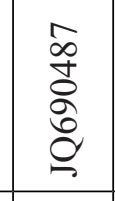 & $\begin{array}{l}\vec{\sigma} \\
\dot{0} \\
\dot{0} \\
\stackrel{g}{2} \\
\end{array}$ \\
\hline$\$$ & 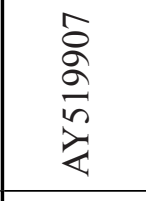 & $\begin{array}{l}\infty \\
0 \\
\infty \\
\infty \\
n \\
\\
\end{array}$ & 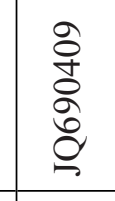 & 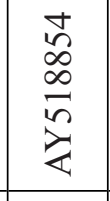 & 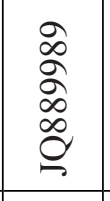 & 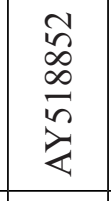 & 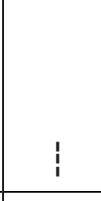 & 1 & 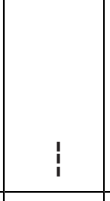 & 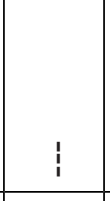 & 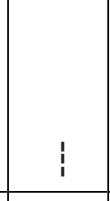 & 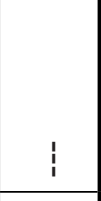 \\
\hline 蛋 & $\frac{\infty}{0}$ & 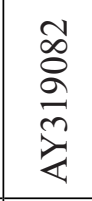 & $\begin{array}{l}\infty \\
0 \\
+ \\
0 \\
0 \\
0\end{array}$ & $\begin{array}{l}\vec{m} \\
\frac{\overrightarrow{2}}{2} \\
\overrightarrow{4}\end{array}$ & $\begin{array}{l}\infty \\
\infty \\
\infty \\
\infty \\
\infty \\
\stackrel{0}{0}\end{array}$ & 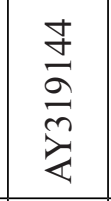 & \begin{tabular}{l}
$\infty$ \\
\multirow{2}{*}{} \\
0 \\
0 \\
0 \\
\end{tabular} & 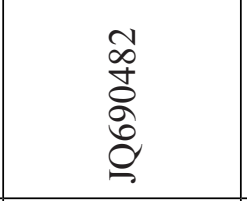 & 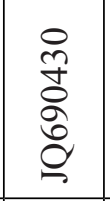 & 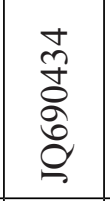 & 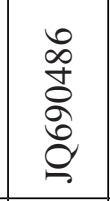 & $\begin{array}{l}\stackrel{2}{0} \\
\stackrel{+}{\circ} \\
\stackrel{0}{0} \\
0\end{array}$ \\
\hline$\stackrel{\widetilde{Z}}{\Omega}$ & 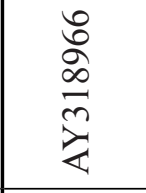 & 1 & 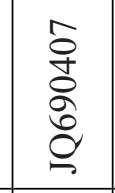 & 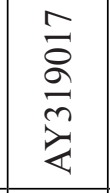 & 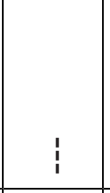 & 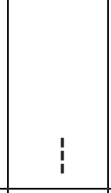 & $\vdots$ & 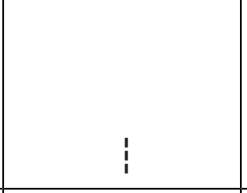 & 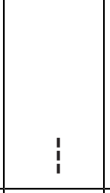 & $\vdots$ & 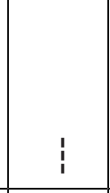 & 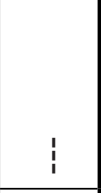 \\
\hline 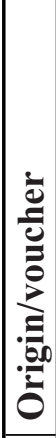 & 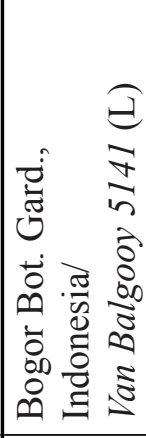 & 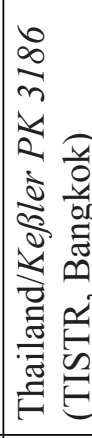 & 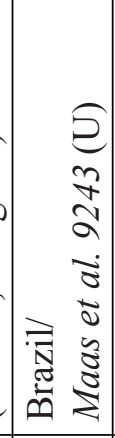 & 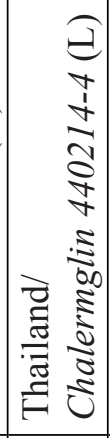 & 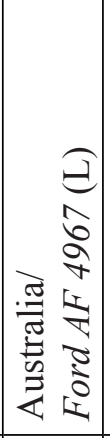 & 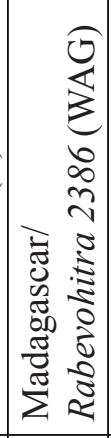 & 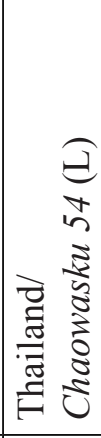 & 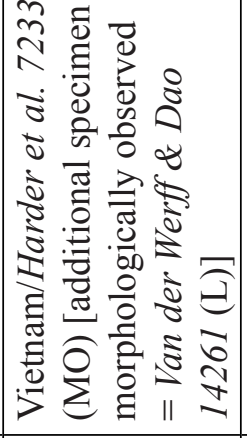 & 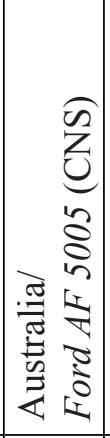 & 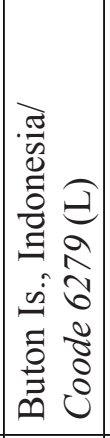 & 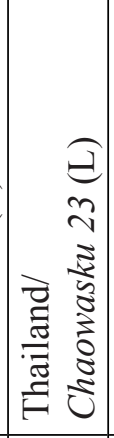 & 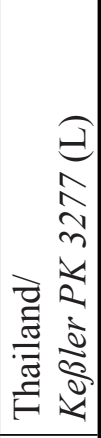 \\
\hline $\mid \begin{array}{c}: \\
\overline{\mathscr{J}} \\
\bar{n}\end{array}$ & 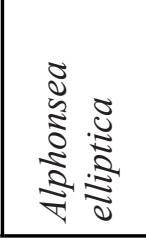 & 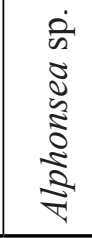 & 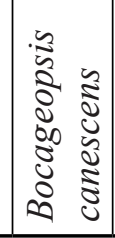 & 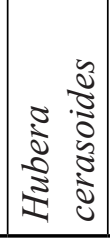 & 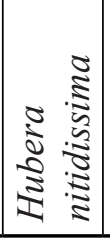 & 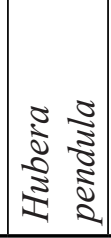 & 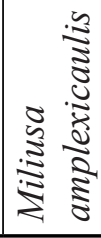 & 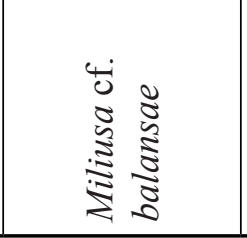 & 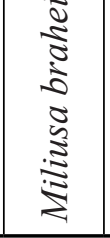 & 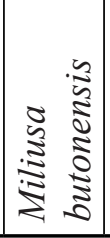 & 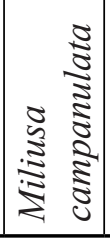 & 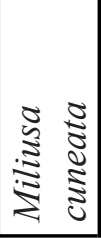 \\
\hline
\end{tabular}


CHAOWASKU T. \& KEßLER P.J.A., Phylogeny and new species of Miliusa (Annonaceae)

\begin{tabular}{|c|c|c|c|c|c|c|c|c|c|c|c|}
\hline 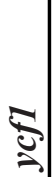 & $\begin{array}{l}\hat{\alpha} \\
\text { ᄋे } \\
\stackrel{8}{0} \\
\stackrel{0}{0}\end{array}$ & $\begin{array}{l}\overrightarrow{8} \\
\text { \& } \\
8 \\
\stackrel{8}{0}\end{array}$ & 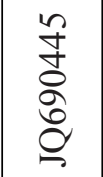 & 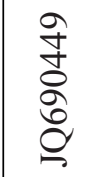 & 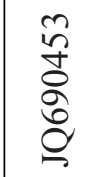 & 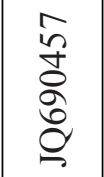 & \begin{tabular}{l}
$\overline{0}$ \\
\multirow{2}{0}{} \\
8 \\
0 \\
0
\end{tabular} & 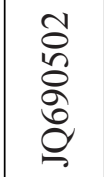 & $\begin{array}{l}n \\
0 \\
0 \\
0 \\
0 \\
0\end{array}$ & 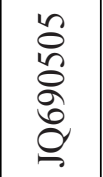 & 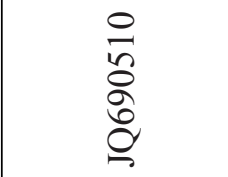 \\
\hline 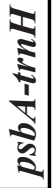 & $\begin{array}{l}\circ \\
\stackrel{2}{0} \\
\stackrel{2}{0} \\
\stackrel{0}{0}\end{array}$ & $\begin{array}{l}\stackrel{+}{8} \\
\text { \& } \\
8 \\
\stackrel{2}{0}\end{array}$ & 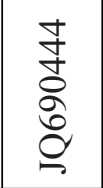 & $\begin{array}{l}\stackrel{\infty}{\&} \\
\stackrel{8}{\circ} \\
\stackrel{0}{0}\end{array}$ & 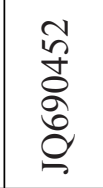 & 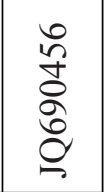 & 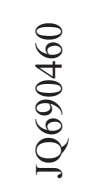 & 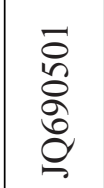 & \begin{tabular}{l} 
ț \\
\multirow{2}{0}{} \\
8 \\
0 \\
0
\end{tabular} & 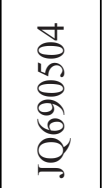 & 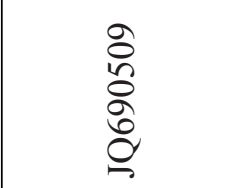 \\
\hline $\mid \begin{array}{l}\mathbf{3} \\
\mathbf{3} \\
\mathbf{3}\end{array}$ & 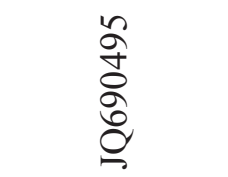 & 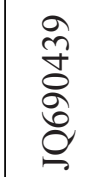 & 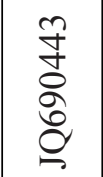 & 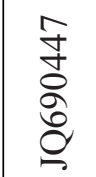 & 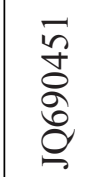 & 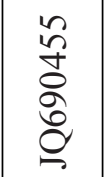 & 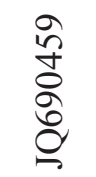 & $\begin{array}{l}8 \\
8 \\
0 \\
8 \\
0 \\
0\end{array}$ & $\begin{array}{l}\hat{0} \\
\text { Oे } \\
8 \\
0 \\
0\end{array}$ & 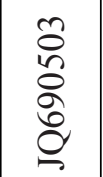 & 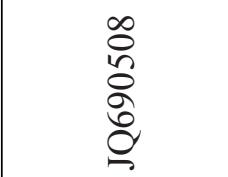 \\
\hline 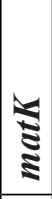 & $!$ & 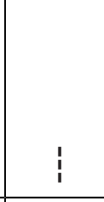 & 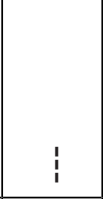 & 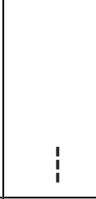 & 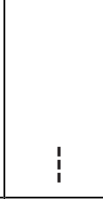 & 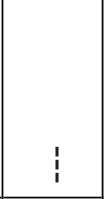 & 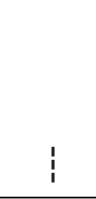 & 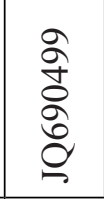 & 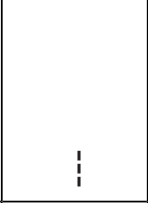 & 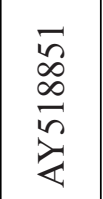 & $\begin{array}{l}\hat{0} \\
0 \\
0 \\
8 \\
0 \\
0\end{array}$ \\
\hline$\frac{1}{5}$ & 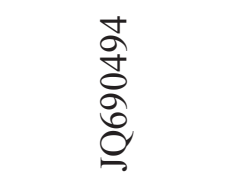 & 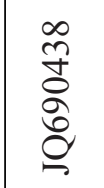 & 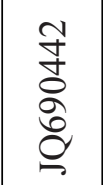 & 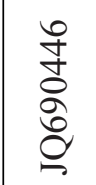 & 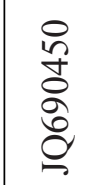 & 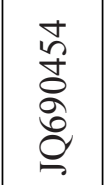 & 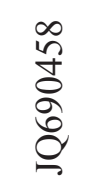 & 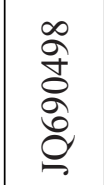 & 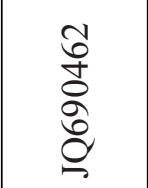 & $\begin{array}{l}\text { ô } \\
\frac{a}{2} \\
\frac{m}{2}\end{array}$ & 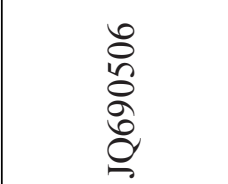 \\
\hline : & $!$ & $!$ & $\vdots$ & $!$ & 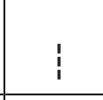 & 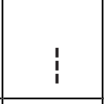 & 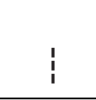 & 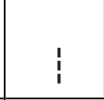 & 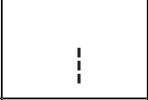 & 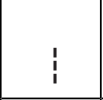 & 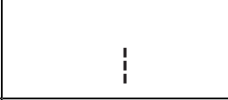 \\
\hline 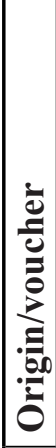 & 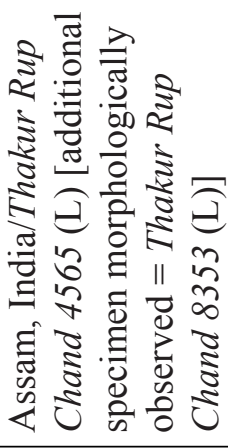 & 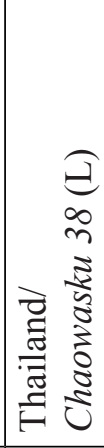 & 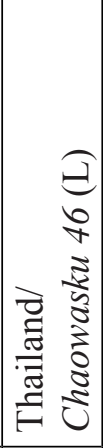 & 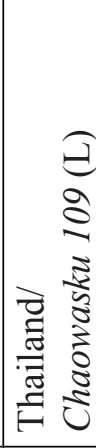 & 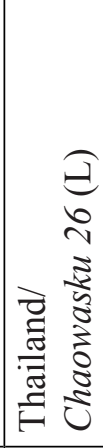 & 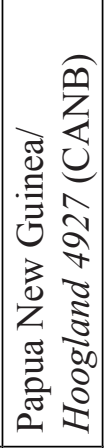 & 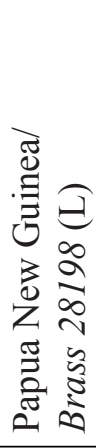 & 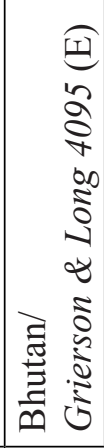 & 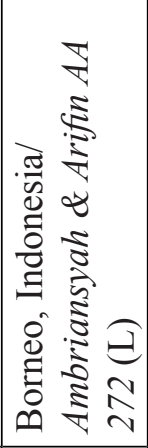 & 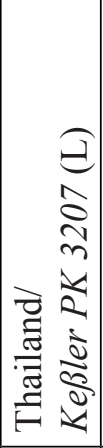 & 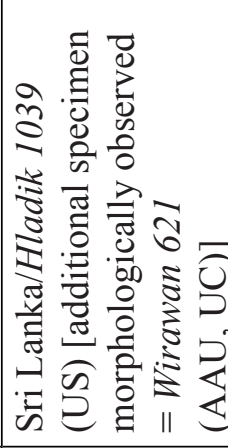 \\
\hline 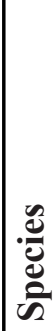 & 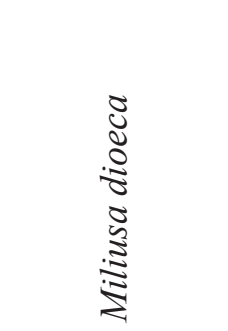 & 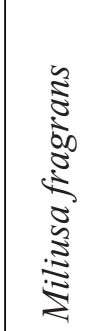 & 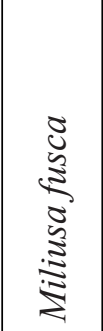 & 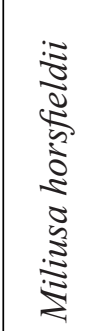 & 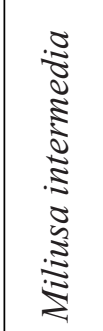 & 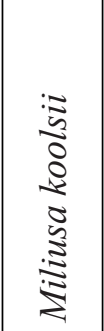 & 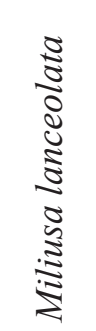 & 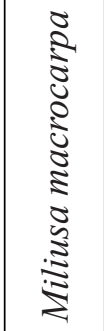 & 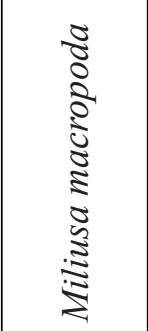 & 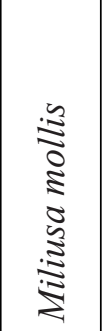 & 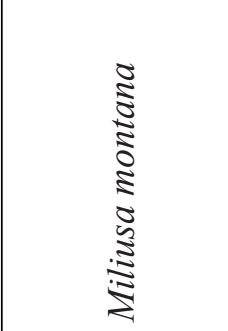 \\
\hline
\end{tabular}




\begin{tabular}{|c|c|c|c|c|c|c|c|c|c|c|c|c|c|c|c|}
\hline$\stackrel{5}{5}$ & \begin{tabular}{l}
$\hat{\sigma}$ \\
\multirow{0}{0}{} \\
8 \\
0 \\
0
\end{tabular} & 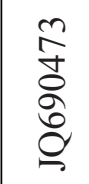 & 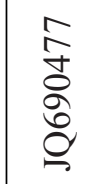 & 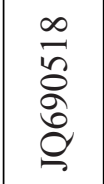 & 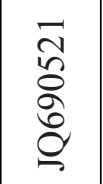 & 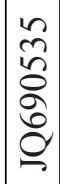 & 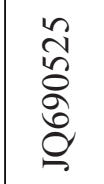 & 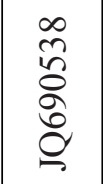 & 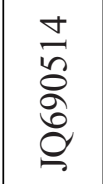 & 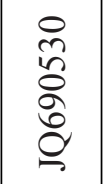 & $\begin{array}{l}\hat{2} \\
\hat{\sigma} \\
\infty \\
\infty \\
\stackrel{\theta}{0}\end{array}$ & 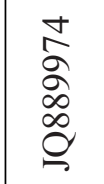 & $\begin{array}{l}8 \\
8 \\
+ \\
8 \\
0 \\
0 \\
0\end{array}$ & $\begin{array}{l}\frac{\infty}{\sigma} \\
\stackrel{8}{0} \\
\stackrel{0}{0} \\
\varrho\end{array}$ & 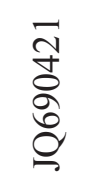 \\
\hline 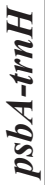 & 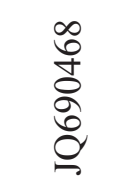 & 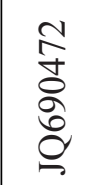 & 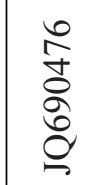 & 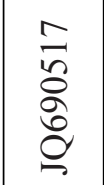 & 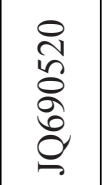 & 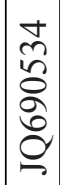 & 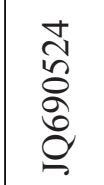 & 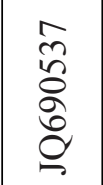 & $\begin{array}{l}\frac{m}{n} \\
\frac{0}{0} \\
\stackrel{0}{0}\end{array}$ & 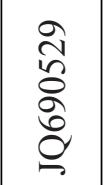 & $\begin{array}{l}\infty \\
\stackrel{\infty}{\circ} \\
\infty \\
\infty \\
\stackrel{0}{0}\end{array}$ & $\begin{array}{l}\stackrel{2}{\hat{\sigma}} \\
\stackrel{2}{2} \\
\infty \\
\stackrel{0}{0}\end{array}$ & 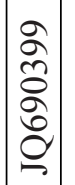 & 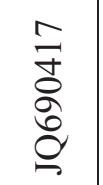 & 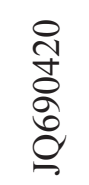 \\
\hline$\$$ & \begin{tabular}{l}
$\hat{0}$ \\
\multirow{0}{0}{} \\
8 \\
0 \\
$\stackrel{0}{0}$
\end{tabular} & 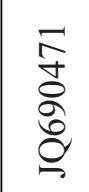 & 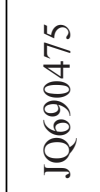 & 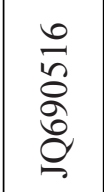 & $\begin{array}{l}\stackrel{a}{\check{n}} \\
\stackrel{2}{0} \\
\stackrel{0}{0}\end{array}$ & $\begin{array}{l}n \\
\hat{n} \\
\hat{2} \\
\hat{2} \\
\varrho \\
\varrho\end{array}$ & 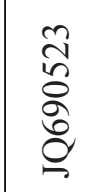 & 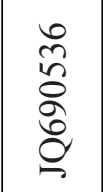 & 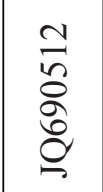 & 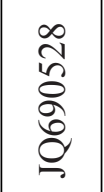 & $\begin{array}{l}\infty \\
\infty \\
\curvearrowright \\
\infty \\
\infty \\
\stackrel{\theta}{\theta}\end{array}$ & \begin{tabular}{l}
\multirow{\infty}{\infty}{} \\
$\stackrel{2}{\infty}$ \\
$\infty$ \\
$\stackrel{0}{0}$
\end{tabular} & 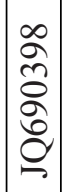 & 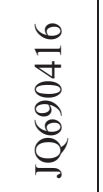 & 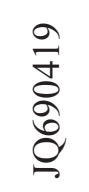 \\
\hline$\$$ & $\mid$ & $\dot{1}$ & $!$ & $\mid$ & \begin{tabular}{l}
0 \\
$\infty$ \\
$\infty$ \\
$\infty$ \\
\\
\multirow{2}{*}{}
\end{tabular} & $\begin{array}{l}\sqrt{2} \\
\tilde{n} \\
2 \\
\delta \\
\delta \\
\varrho \\
\varrho \\
0\end{array}$ & 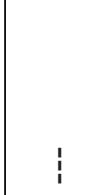 & 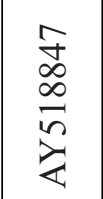 & $\mid$ & 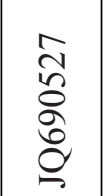 & $\begin{array}{l}n \\
n \\
\infty \\
\infty \\
\sqrt{n} \\
\vdots\end{array}$ & 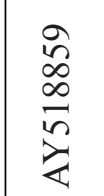 & $\begin{array}{l}\hat{\alpha} \\
\hat{\tilde{o}} \\
\hat{\sigma} \\
\stackrel{0}{0}\end{array}$ & 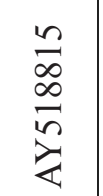 & $\begin{array}{l}\infty \\
\infty \\
\infty \\
\ddot{n} \\
\check{<}\end{array}$ \\
\hline$\frac{1}{5}$ & 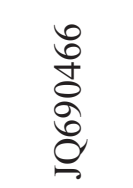 & 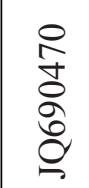 & 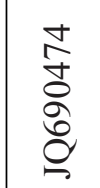 & 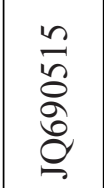 & 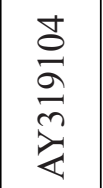 & $\begin{array}{l}\vec{n} \\
\tilde{2} \\
\delta \\
\hat{\delta} \\
\varrho \\
0\end{array}$ & 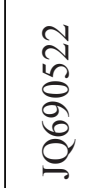 & $\frac{\stackrel{r}{\circ}}{\frac{a}{2}}$ & 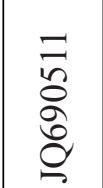 & 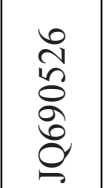 & $\begin{array}{l}\frac{8}{\sigma} \\
\frac{\pi}{2} \\
\frac{\pi}{2}\end{array}$ & $\frac{\hat{0}}{\frac{a}{2}}$ & 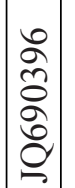 & $\frac{a}{\frac{a}{\sigma}}$ & $\begin{array}{l}\vec{N} \\
\frac{\vec{\sigma}}{2} \\
\frac{2}{<}\end{array}$ \\
\hline$\stackrel{\Xi}{=}$ & 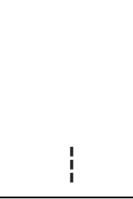 & 1 & $!$ & $!$ & 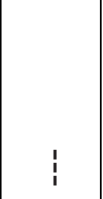 & $\vdots$ & 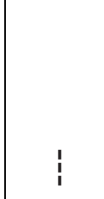 & $\begin{array}{l}\stackrel{n}{\hat{\sigma}} \\
\frac{\infty}{2} \\
\frac{\alpha}{\alpha}\end{array}$ & 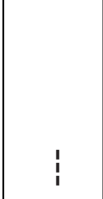 & 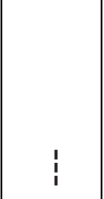 & 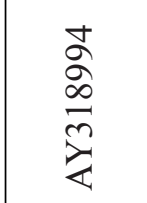 & $\dot{q}$ & $\begin{array}{l}n \\
\hat{2} \\
\tilde{\delta} \\
\delta \\
0 \\
\varrho\end{array}$ & $\begin{array}{l}0 \\
8 \\
\circ \\
\frac{2}{2} \\
\frac{2}{4}\end{array}$ & $\begin{array}{l}\infty \\
\stackrel{2}{0} \\
\frac{2}{2} \\
\stackrel{2}{<}\end{array}$ \\
\hline 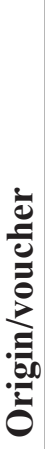 & 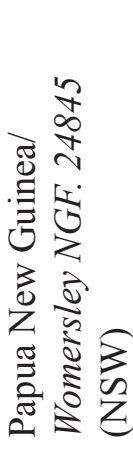 & 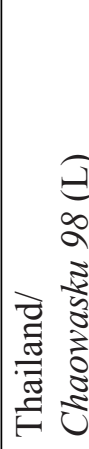 & 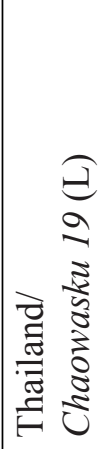 & 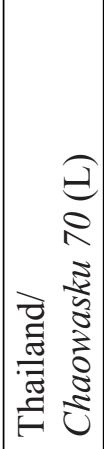 & 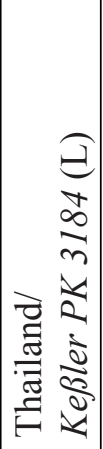 & 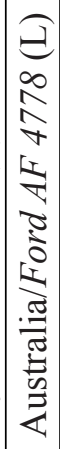 & 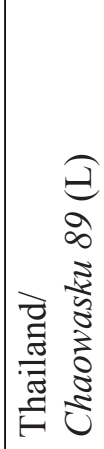 & 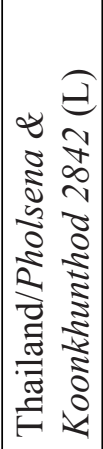 & 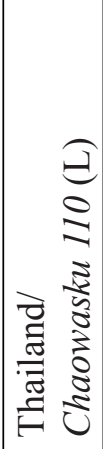 & 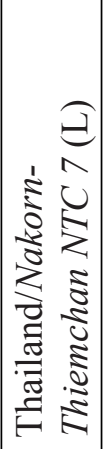 & 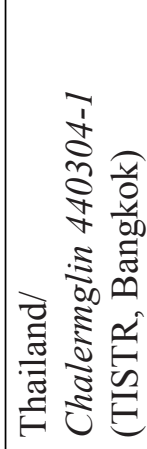 & 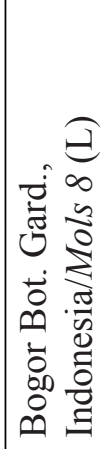 & 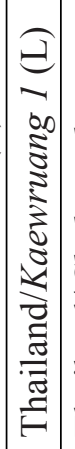 & 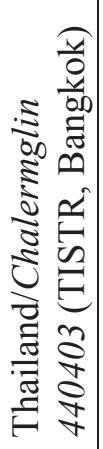 & 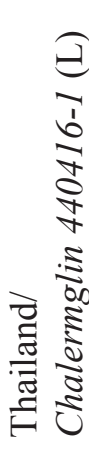 \\
\hline 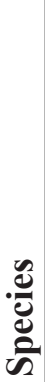 & 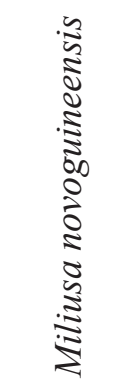 & 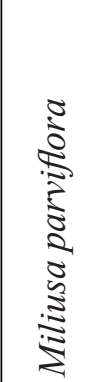 & 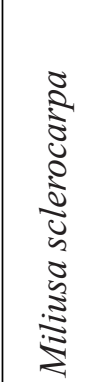 & 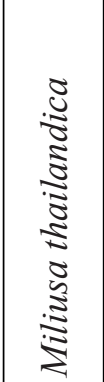 & 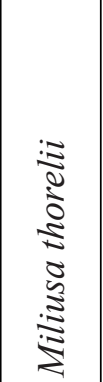 & 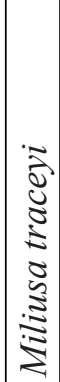 & 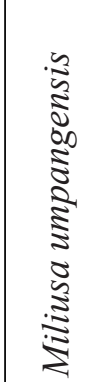 & 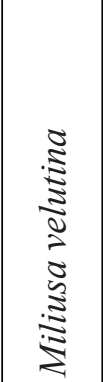 & 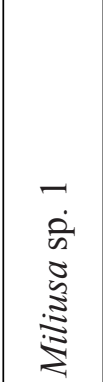 & 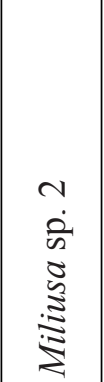 & 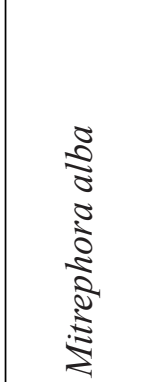 & 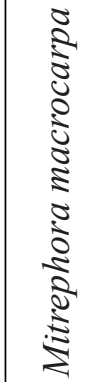 & 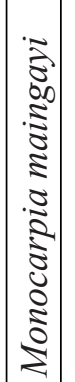 & 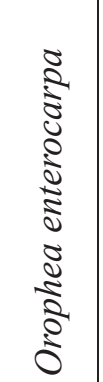 & $\frac{5}{\frac{0}{0}} \frac{0}{8}$ \\
\hline
\end{tabular}




\begin{tabular}{|c|c|c|c|}
\hline స్త & \begin{tabular}{l}
$n$ \\
\multirow{2}{*}{} \\
$\stackrel{0}{0}$ \\
$\stackrel{8}{g}$
\end{tabular} & 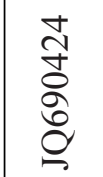 & $\begin{array}{l}\text { సे } \\
\text { Ð } \\
\stackrel{0}{0}\end{array}$ \\
\hline 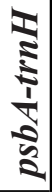 & 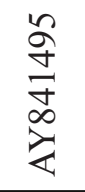 & 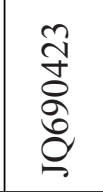 & 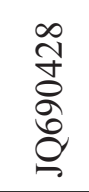 \\
\hline 标 & 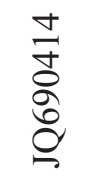 & 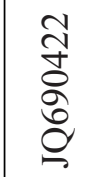 & \begin{tabular}{l}
$\widehat{N}$ \\
\multirow{2}{\circ}{} \\
$\stackrel{0}{0}$ \\
$\stackrel{0}{0}$
\end{tabular} \\
\hline $\begin{array}{l}\mathbf{Z} \\
\mathbf{Z}\end{array}$ & 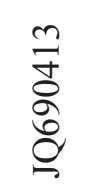 & $\begin{array}{l}2 \\
\infty \\
\infty \\
\infty \\
2 \\
\gtrless\end{array}$ & 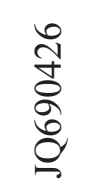 \\
\hline \begin{tabular}{l}
5 \\
\multirow{2}{5}{} \\
$\mathbf{5}$
\end{tabular} & 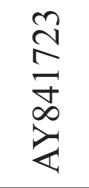 & \begin{tabular}{l}
$\hat{a}$ \\
$\frac{a}{2}$ \\
\multirow{2}{*}{}
\end{tabular} & 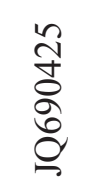 \\
\hline $\begin{array}{l}\bar{\Xi} \\
\Xi\end{array}$ & 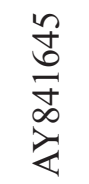 & $\frac{m}{\frac{m}{2}}$ & 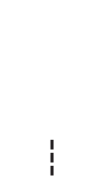 \\
\hline 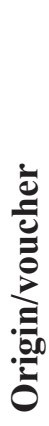 & 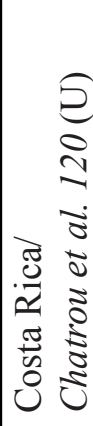 & 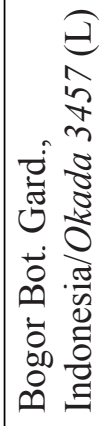 & 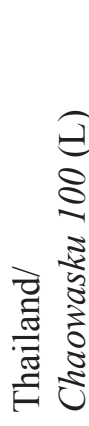 \\
\hline 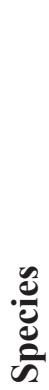 & 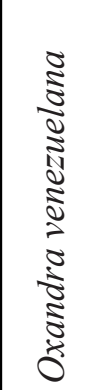 & 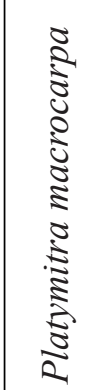 & 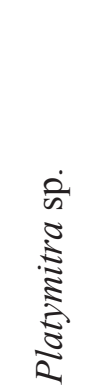 \\
\hline
\end{tabular}

